\title{
Spatial variability in Ontario Cabernet Franc vineyards: I. Interrelationships among soil composition, soil texture, soil and vine water status
}

\author{
Andrew G. Reynolds* and J avad Hakimi Rezaei \\ Cool Climate Oenology and Viticulture Institute, Brock University, St. Catharines, ON, Canada L2S 3A1. \\ *E-mail: areynolds@brocku.ca
}

\begin{abstract}
Spatial variability of vine water status and its relationship to soil moisture (SM) and physical properties was studied in ten vineyard blocks of Vitis vinifera L. Cabernet Franc in the Niagara Peninsula, Ontario, using geomatic techniques. Soil texture, soil chemical composition, SM, and leaf water potential ( $\psi$; vine water status), were determined on $\approx 80$ sentinel vines per vineyard. Water status zones were identified in vineyard-specific GIS-generated maps using leaf $\psi$ and SM measurements. SM was temporally consistent for nine of ten sites (2005-2006), all sites (2006-2007), and eight sites (2005-2007). Vine water status was temporally consistent for two sites (2005-2006) and three sites (2006-2007), but leaf $\psi$ zones were transient at some sites with temporally variable spatial distribution (except one site with consistent water status zones 2005-2007). SM and leaf $\psi$ consistently were directly-correlated spatially with \% clay, $\%$ organic matter $(\mathrm{OM})$, cation exchange capacity $(\mathrm{CEC})$, soil $\mathrm{pH}$, base saturation (BS), soil $\mathrm{K} / \mathrm{Ca} / \mathrm{Mg}$. Low SM and water status zones were related to low \% clay, OM, CEC, soil $\mathrm{pH}, \mathrm{BS}$, soil $\mathrm{K} / \mathrm{Ca} / \mathrm{Mg}$ zones. This indicates that precision viticulture may be applied to soil texture, SM, or leaf $\psi$-based vineyard sub-zones that could relate to differing quality levels.
\end{abstract}

Key words: Global positioning systems, geographic information systems, soil moisture, leaf water potential

\section{Introduction}

Several recent studies have indicated that temporally stable spatial variation in vineyards exists in terms of vegetative growth, yield, and fruit composition (Bramley, 2001; Hall et al., 2002). However, the use of geospatial tools such as geographic information systems (GIS) coupled with remote sensing techniques for the study of vineyards is a relatively recent development that has yet seen few applications. GIS was used to map 2,000 ha of the Loire Valley, in terms of soil type and rootstock, but the information was not used to find possible relationships such as those between soil and wine varietal typicity. In California, GIS was used to map viticultural regions in terms of phylloxera damage based upon leaf reflectance (Johnson et al., 1996). These techniques were also used to relate yields and soluble solids concentrations of Concord (Davenport et al., 2001), to distinguish between high and low vigor "management zones" in Cabernet Sauvignon and Zinfandel vineyards in California (Greenspan and O'Donnell, 2001), and in vineyards throughout Australia (Bramley, 2005). More recently, geomatic tools were used to assess impact of vigor zones on anthocyanin and phenolic composition in Oregon Pinot noir (Cortell et al., 2006).

In Ontario, vineyards are often located on sites that contain heterogeneous soil types. It was initially hypothesized that soil texture would play a minor role in the widely accepted terroir effect, in terms of its determination of yield components, fruit composition (including aroma compounds), and wine sensory attributes, and that vine vigor, vine water status, crop size and fruit environment would play the major roles. This hypothesis was initially tested using geospatial tools in five commercial Chardonnay vineyards in the Niagara Peninsula of Ontario in
1998 to 2002, with the conclusion that vine vigor appeared to impact fruit composition and wine sensory attributes to a greater degree than soil texture (Reynolds and de Savigny, 2001). A study in a 4-ha Riesling vineyard was another attempt using geomatic tools to understand direct and independent soil and vine vigor effects on yield components, berry, must and wine composition, and wine sensory attributes (Reynolds et al., 2007; 2010a). Spatial variability of monoterpenes led to the identification of sub-blocks that were designated as having potentially higher wine value. Recent studies in Ontario have definitively linked soil and vine water status to sensory attributes in Riesling (Willwerth et al., 2010) and have shown links between Riesling varietal typicity and both soil texture and vine size (Reynolds et al. 2007; 2010a; Willwerth et al., 2010). Remote sensing has also been used to correlate canopy spectral reflectance to vine water status, yield, vine size, and berry monoterpenes (Reynolds et al., 2010b).

This investigation was initiated to identify the major factors that contribute to the terroir effect in the vineyards of the Niagara Peninsula in Ontario. The overall objective of this study was to determine spatial variability with respect to soil composition, soil texture, soil and vine water status in ten Cabernet Franc vineyards in the Niagara Peninsula of Ontario, and to explore whether relationships existed between these variables. The specific objectives of this research were: (i) to demonstrate the influences of soil texture, soil water content, and vine water status on vine and fruit development within vineyard blocks and to delineate these terroir effects using GPS/GIS; and (ii) to elucidate the relationships between soil and vine water status and wine sensory properties. It was hypothesized that: (i) consistent water status zones could be identified within vineyard blocks and, (ii) vine water status would play a major role in fruit composition 
and sensory characteristics of Cabernet Franc wines, whereas soil type might play a role through its water holding capacity and water supply to the vine. This project therefore had three distinct phases; the first phase, described in this paper, examined spatial relationships among soil characteristics, soil moisture and vine water status using GPS/GIS technology. The second phase examined relationships between soil and vine water status and vine performance (yield components and vine size) as well as berry composition (including anthocyanins and phenols) using GPS/GIS technology. The third phase consisted of the sensory characterization of wines produced from both sub-appellations as well as regions of different water status, delineated through GIS using sensory descriptive analysis (Hakimi Rezaei and Reynolds, 2010a,b).

\section{Materials and methods}

Site selection and site features: Ten commercial vineyard blocks of Cabernet Franc were selected, one each in the ten sub-appellations of the Niagara Peninsula including: Niagara Lakeshore, St. David's Bench, Creek Shores, Four Mile Creek, Niagara River, Lincoln Lakeshore, Beamsville Bench, Short Hills Bench, Vinemount Ridge, and Twenty Mile Bench for the project

Table 1. General features of Niagara Peninsula Cabernet Franc vineyards used for elucidation of terroir study, 2005-07. Vineyard site abbreviations used in the text are indicated

\begin{tabular}{|c|c|c|c|c|c|}
\hline \multirow[t]{2}{*}{ Variable } & \multicolumn{5}{|c|}{ Sites } \\
\hline & $\begin{array}{c}\text { Château des Charmes } \\
\text { (CDC) }\end{array}$ & Reif & Hernder & Buis & $\begin{array}{l}\text { Henry of Pelham } \\
\text { (HOP) }\end{array}$ \\
\hline VQA sub-appellation & St. David's Bench & Niagara River & $\begin{array}{l}\text { Four Mile Creek } \\
\text { (Lakeshore Plain) }\end{array}$ & Niagara Lakeshore & Short Hills Bench \\
\hline Area of vineyard block (ha) & 2.29 & 0.61 & 2.63 & 0.71 & 2.17 \\
\hline Number of sentinel vines & 80 & 84 & 70 & 77 & 80 \\
\hline $\begin{array}{l}\text { Sentinel vines per ha } \\
\text { Soil series } \\
\text { (Kingston and Presant, 1989) }\end{array}$ & $\begin{array}{c}35 \\
\text { Toledo } 7\end{array}$ & $\begin{array}{c}138 \\
\text { Chinguacousy } 7\end{array}$ & $\begin{array}{c}27 \\
\text { Chinguacousy } 1\end{array}$ & $\begin{array}{c}108 \\
\text { Chinguacousy } 19 \\
\text { (Red Phase; CGU.R) }\end{array}$ & $\begin{array}{c}37 \\
\text { Beverley } 1\end{array}$ \\
\hline Parent materials & $\begin{array}{l}\text { Lacustrine } \\
\text { silty clay }\end{array}$ & $\begin{array}{l}\text { Washed reddish } \\
\text { hued clay loam } \\
\text { till, modified by } \\
\text { lacustrine processes }\end{array}$ & $\begin{array}{l}\text { Mainly clay } \\
\text { loam till }\end{array}$ & $\begin{array}{l}\text { Mainly reddish } \\
\text { hued clay }\end{array}$ & $\begin{array}{l}\text { Mainly lacustrine } \\
\text { silty clay }\end{array}$ \\
\hline Soil drainage & Imperfect to poor & Imperfect & Imperfect & Imperfect to poor & Imperfect \\
\hline Rootstock & 3309 & 3309 & 3309 & $\mathrm{SO} 4+3309$ & $\mathrm{SO} 4$ \\
\hline $\begin{array}{l}\text { Vine age at initiation of trial } \\
\text { (year planted) }\end{array}$ & 1992 & 1999 & 1998 & 1988 & 1999 \\
\hline Vine spacing (m; row $\mathrm{x}$ vine) & $2.2 \times 0.9$ & $3.0 \times 1.3$ & $2.8 \times 1.25$ & $2.9 \times 1.3$ & $2.7 \times 1.3$ \\
\hline $\begin{array}{l}\text { Number of rows; vines per } \\
\text { row }\end{array}$ & $\begin{array}{l}27 \text { rows } \\
376 \text { vines/ row }\end{array}$ & $\begin{array}{c}6 \text { rows } \\
284 \text { vines/ row }\end{array}$ & $\begin{array}{l}58 \text { rows } \\
137 \text { vines/ row }\end{array}$ & $\begin{array}{c}20 \text { rows } \\
118 \text { vines/ row }\end{array}$ & $\begin{array}{c}29 \text { rows } \\
240 \text { vines/ row }\end{array}$ \\
\hline Training system & Guyot & Pendelbogen & Guyot & Scott Henry & Guyot \\
\hline \multirow[t]{2}{*}{ Floor management } & Clean cultivated & $\begin{array}{l}\text { Alternate sod (rows } \\
\text { alternate between sod } \\
\text { and clean cultivation) }\end{array}$ & Alternate sod & Clean cultivated & Alternate sod \\
\hline & $\begin{array}{l}\text { Harbour Estate } \\
\text { (Harbour) }\end{array}$ & Morrison Vineyard & Cave Spring & George Vineyard & Vieni Estate \\
\hline VQA sub-appellation & Creek Shores & 20 Mile Bench & Beamsville Bench & Lincoln Lakeshore & Vinemount Moraine \\
\hline Area of vineyard block (ha) & 1.67 & 0.97 & 1.54 & 1.23 & 1.19 \\
\hline Number of sentinel vines & 80 & 72 & 75 & 72 & 72 \\
\hline Sentinel vines per ha & 47 & 74 & 49 & 59 & 61 \\
\hline $\begin{array}{l}\text { Soil series } \\
\text { (Kingston and Presant, 1989) }\end{array}$ & $\begin{array}{l}\text { Vittoria } 16 \text { (Red } \\
\text { Phase; VIT.R) }\end{array}$ & Cashel 3 & $\begin{array}{c}\text { Chinguacousy } 14 \\
\text { (Loamy Phase; (CGU.L)( }\end{array}$ & $\begin{array}{c}\text { Chinguacousy } 24 \\
\text { Washed Phase; CGU.W) }\end{array}$ & Chinguacousy 1 \\
\hline Parent materials & $\begin{array}{l}40-100 \mathrm{~cm} \text { reddish- } \\
\text { hued sandy textures } \\
\text { over lacustrine silt } \\
\text { loam }\end{array}$ & $\begin{array}{l}\text { 40-100 cm lacustrine } \\
\text { silty clay over } \\
\text { clay loam } \\
\text { till }\end{array}$ & $\begin{array}{l}15-40 \mathrm{~cm} \text { loamy } \\
\text { textures over } \\
\text { clay loam } \\
\text { till }\end{array}$ & $\begin{array}{l}\text { Washed clay loam } \\
\text { till, modified by } \\
\text { lacustrine } \\
\text { processes }\end{array}$ & $\begin{array}{l}\text { Mainly } \\
\text { clay } \\
\text { loam } \\
\text { till }\end{array}$ \\
\hline Soil drainage & Imperfect & Moderately well & Imperfect & Imperfect-poor & Imperfect \\
\hline Rootstock & Riparia Gloire & $\mathrm{SO} 4$ & $101-14$ & $\mathrm{SO} 4$ & $\mathrm{SO} 4$ \\
\hline $\begin{array}{l}\text { Vine age at initiation of trial } \\
\text { (year planted) }\end{array}$ & 1999 & 1999 & 1999 & 1995 & 1998 \\
\hline $\begin{array}{l}\text { Vine spacing } \\
\text { (m; row } x \text { vine) }\end{array}$ & $2.7 \times 1.5$ & $2.9 \times 1.3$ & $2.7 \times 1.4$ & $2.7 \times 1.4$ & $2.0 \times 1.25$ \\
\hline $\begin{array}{l}\text { Number of rows; vines per } \\
\text { row }\end{array}$ & $\begin{array}{c}37 \text { rows } \\
105 \text { vines/ row }\end{array}$ & $\begin{array}{c}18 \text { rows } \\
155 \text { vines/ row }\end{array}$ & $\begin{array}{c}23 \text { rows } \\
233 \text { vines/ row }\end{array}$ & $\begin{array}{l}24 \text { rows } \\
137 \text { vines/ row }\end{array}$ & $\begin{array}{c}30 \text { rows } \\
135 \text { vines/ row }\end{array}$ \\
\hline Training system & Scott Henry & Scott Henry & Guyot & Guyot & Guyot \\
\hline Floor management & Clean cultivated & Clean cultivated & Alternate sod & Sod every row & Alternate sod \\
\hline
\end{tabular}


in spring of 2005 (Table 1). General features of each vineyard including VQA sub appellation (Vintners' Quality Alliance; http:// www.vqaontario.com/appellations), area of vineyard, number of sentinel vines, soil series, parental material, soil drainage, rootstock, year of planting, vine spacing, and floor management were recorded for each vineyard. Soil parent material at the sites ranged from lacustrine silty clay, reddish hued clay, and loamy texture to reddish hued sandy texture. Soil drainage was imperfect to poor, imperfect or moderately well drained. Area of vineyard blocks varied from 0.6 ha (Reif) to 2.6 ha (Hernder). Vine spacing varied from $2.0 \mathrm{~m} \mathrm{x} 1.25 \mathrm{~m}$ (vine $\mathrm{x}$ row) at Vieni Estate to $3.0 \mathrm{x}$ $1.3 \mathrm{~m}$ at Reif. Training system was Guyot, pendelbogen, or Scott Henry. Floor management at some sites was clean cultivation and at others was sod maintained in alternate rows. Rootstocks were $101-14,3309$ or SO4 and vine age varied from 7 to 18 years. No changes in management were made at these sites during the period of study. Weather data (Table 2) were compiled for each site from Weather Innovations Inc. (www.weatherinnovations.com).

GPS and GIS: A Raven Invicta 115 GPS Receiver (Raven Industries, Sioux Falls, SD, USA) with 1.0 to $1.4 \mathrm{~m}$ accuracy was used to delineate the shape of each vineyard block as well as to geolocate each sentinel vine. The number of sentinel vines varied from 27 to 138 per ha. Bramley (2001) reported use of 26 sentinel vines per ha in studies in Sunraysia and Coonawarra in Australia. Using GIS programs MapInfo Professional and Vertical Mapper (Northwood GeoScience, Ottawa, ON, Canada), spatial maps of all variables were created, and water status zones were mapped based on vine leaf $\psi$ values (Table 3 ). The inverse distance weighting (IDW) interpolation algorithm was used to construct the grid files. IDW interpolation algorithm was chosen vs. kriging due to uneven nature of vineyards. In this method, closer grid points have more influence on the calculation of unknown grid values compared to the points that are further away. With regard to power, the exponential option was selected, which enables the user to define the exponential rate of decreasing the influence of neighboring points that lie further from the point being calculated (Proffitt et al., 2006). The lowest value was chosen for the exponential rate. The values in each zone of the constructed maps were the minimum values of the range of values for that zone. Where possible, five zones with equal ranges were delineated for each variable in all maps. The range of values for each variable was not the same in each vineyard, and therefore the ranges were of differing magnitudes. Fewer than five zones were delineated in vineyard blocks with low variability. Spatial correlation analysis was performed in Vertical Mapper; $r$ values $>0.8$ were assumed to be particularly meaningful in so far as these suggested significant spatial correlation between different variables within seasons, or temporal consistency between like variables between seasons. For two independent variables sampled at a density of 72 to 80 observations per site (e.g. soil moisture), $r$ values, 0.330 and 0.269 were equivalent to $p$ values of $<0.01$ and 0.05 , respectively; for a density of 20 observations per site (e.g. soil composition, leaf $\psi$ ), r values, 0.606 and 0.509 were equal to $p$ values of $<0.01$ and 0.05 , respectively (Steel and Torrie, 1960).

For wine making purposes, each vineyard block was separated into three zones of high, medium, and low water status (HWS, MWS, LWS, respectively) based on the mean leaf $\psi$ maps for each season. Grapes from each of these water status zones were harvested separately based on the leaf $\psi$ map of each vineyard block in both 2005 and 2006 and were used to make wine. Therefore, from each vineyard block, three wine categories (high,

Table 2. Growing degree days (GDD) and precipitation for ten sites in the Niagara Peninsula, Ontario, 2005-2007. Data courtesy of Weather Innovations Inc., Chatham, ON

\begin{tabular}{|c|c|c|c|c|c|c|c|}
\hline \multirow[t]{2}{*}{ Name of vineyard block } & \multirow[t]{2}{*}{ Name of sub-appellation } & \multicolumn{3}{|c|}{ Growing degree days (GDD) } & \multicolumn{3}{|c|}{ Precipitation (mm) May - October } \\
\hline & & 2005 & 2006 & 2007 & 2005 & 2006 & 2007 \\
\hline Buis & Niagara Lakeshore & 1490 & 1417 & 1579 & 483.3 & NA & 247.6 \\
\hline Château des Charmes & St. David's Bench & 1681 & 1474 & 1646 & 476.5 & 461.9 & 219.8 \\
\hline Harbour Estate & Creek Shores & 1672 & 1457 & 1606 & 436.3 & 534.2 & 221.4 \\
\hline Hernder & Four Mile Creek & 1505 & 1471 & 1572 & 457.1 & 566.6 & 181.6 \\
\hline Reif & Niagara River & 1604 & 1449 & 1539 & 498.4 & 631.3 & 163.8 \\
\hline George & Lincoln Lakeshore & 1559 & 1401 & 1420 & 555.9 & 537.7 & 241.4 \\
\hline Cave Spring & Beamsville Bench & 1620 & 1415 & 1679 & 410.2 & 604.1 & 197.8 \\
\hline Henry of Pelham & Short Hills Bench & 1552 & 1412 & 1591 & 466.8 & 507.7 & 172.2 \\
\hline Vieni Estate & Vinemount Ridge & 1565 & 1354 & 1594 & 409.7 & 526.5 & 286.6 \\
\hline Morrison & Twenty Mile Bench & 1667 & 1457 & 1606 & 438.4 & 534.2 & 221.4 \\
\hline
\end{tabular}

Table 3. Mean leaf water potential $(\psi)$ and soil moisture ranges in ten Cabernet Franc sites, Niagara Peninsula, ON, 2005-2007. Measurements were made bi-weekly between July to September

\begin{tabular}{|c|c|c|c|c|c|c|}
\hline \multirow[t]{2}{*}{ Site } & \multicolumn{3}{|c|}{ Leaf $\psi(-\mathrm{MPa})$} & \multicolumn{3}{|c|}{ Soil moisture (\%) } \\
\hline & 2005 & 2006 & 2007 & 2005 & 2006 & 2007 \\
\hline Buis & $1.00-1.35$ & $1.11-1.35$ & $1.14-1.45$ & $14.0-20.4$ & $17.6-32.0$ & $17.2-27.6$ \\
\hline Château des Charmes & $1.20-1.60$ & $1.25-1.50$ & $1.52-1.64$ & $10.9-16.2$ & $19.4-33.5$ & $9.3-24.8$ \\
\hline Hernder Estate & $1.26-1.59$ & $1.29-1.60$ & $1.37-1.60$ & $7.3-13.4$ & $15.1-28.0$ & $6.1-27.7$ \\
\hline Reif & $1.10-1.35$ & $1.07-1.34$ & $1.11-1.34$ & 7.6-13.6 & $11.3-25.6$ & $8.8-21.3$ \\
\hline George & $1.10-1.46$ & $1.01-1.26$ & $1.16-1.50$ & $11.1-15.8$ & $18.1-29.0$ & $12.4-21.7$ \\
\hline Henry of Pelham & $1.10-1.45$ & $1.14-1.37$ & $1.31-1.50$ & $12.0-15.6$ & $18.1-29.7$ & $14.0-25.9$ \\
\hline Cave Spring & $1.20-1.55$ & $1.09-1.24$ & $1.43-1.58$ & $10.7-15.6$ & $21.8-32.7$ & $10.1-20.9$ \\
\hline Harbour Estate & $0.80-1.09$ & $0.90-1.15$ & $0.93-1.12$ & $9.9-13.4$ & $11.7-18.7$ & $3.5-8.5$ \\
\hline Vieni Estate & $1.20-1.45$ & $0.82-1.10$ & $1.38-1.59$ & $9.1-15.7$ & $22.2-35.9$ & $10.7-25.2$ \\
\hline Morrison & $1.21-1.47$ & $0.97-1.24$ & $1.42-1.64$ & $11.0-19.1$ & $21.3-33.9$ & $11.0-20.6$ \\
\hline
\end{tabular}


medium, and low water status) were made with three replicates of each in both years.

Soil sampling and composition: Soil samples were collected from every fourth sentinel vine (7 to 35 vines per ha) with an auger from within the row, 40 to $50 \mathrm{~cm}$ away from the trunk. Soil was taken from a 0 to $45 \mathrm{~cm}$ depth and in total $\approx 350 \mathrm{~g}$ of a homogenized sample was taken. Depending on the area of each vineyard block, 15 to 20 soil samples were taken. Soil samples were analyzed for $\mathrm{pH}$, organic matter $(\mathrm{OM})$, phosphorus $(\mathrm{P})$, potassium $(\mathrm{K})$, magnesium $(\mathrm{Mg})$, calcium $(\mathrm{Ca})$, texture $(\%$ sand, silt, clay), cation exchange capacity (CEC), and base saturation (BS; as \% Ca, Mg, and $\mathrm{K}$ ) using standard procedures [Canadian Society of Soil Science (CSSS), 1993].

Soil water status: Soil moisture data ( $\%$ water by volume) were taken bi-weekly on five separate dates between late June and early September in the 2005 to 2007 growing seasons. Soil moisture was measured at each sentinel vine by time domain reflectometry using a Fieldscout TDR-300 soil moisture probe (Spectrum Technologies Inc., East Plainfield, IL, USA). A total of 72 to 80 vines were measured between $0800 \mathrm{~h}$ and $1800 \mathrm{~h}$. Measurements were taken in the row $\approx 10 \mathrm{~cm}$ from the base of each vine trunk over a $20 \mathrm{~cm}$ depth. Most vineyards in the region contain drain tiles at $\approx 60 \mathrm{~cm}$ depth, which tends to restrict rooting depth, and therefore this depth was considered adequate for determining moisture levels. The mean soil moisture for each sentinel vine was calculated from the five separate readings.

Vine water status: Midday leaf $\psi$ was determined between $1100 \mathrm{~h}$ and $1600 \mathrm{~h}$ for fully exposed, mature leaves of similar physiological stage which showed no visible sign of damage and had been in full sunlight (Turner, 1988). Determinations were made on cloudless days only. Each leaf sample was covered in a plastic bag and sealed immediately after excision at the petiole to suppress transpiration. The leaf petiole was cut with a sharp razor blade and then inserted into a pressure chamber Model 3005 Plant Water Status Console (Soil Moisture Equipment Corp., Santa Barbara, CA, USA). A total of $\approx 20$ leaves per vineyard block were used to estimate leaf $\psi$ for each sampling date. Overall, there were five sampling dates during the growing season; bi-weekly between late June and early September 2005 to 2007 for each site. Data were recorded in negative bar units $(10$ bars $=1 \mathrm{MPa})$.

Data analysis: Within each vineyard block, high and low water status zones were identified accordingly based on GIS- generated maps, and fruit were harvested separately from each zone for yield components data. Fruit composition data were based on individual 100-berry samples collected from each sentinel vine in each site in all three seasons. In each vineyard block, all data were analyzed by analysis of variance based on high and low water status categories using SAS statistical package version 8 (SAS Institute; Cary, NC, USA). Correlation analysis was performed for each vineyard block as well as across all blocks for each year. Principal components analysis (PCA) was performed on all data in each of the three years across all vineyard blocks. Spatial correlation analysis was done by MapInfo and Vertical Mapper (Northwood GeoScience, Ottawa, ON, Canada) at each site and each year by analyzing spatial patterns in the gridfiles for each variable.

\section{Results}

Seasonal weather data for 2005-2007: The three seasons varied in growing degree days (GDD; base $10{ }^{\circ} \mathrm{C}$ ) and precipitation (Table 2). The 2005-07 GDD means ranged from 1495 GDD (Buis, Niagara Lakeshore sub-appellation) to 1578 GDD (Harbour Estates, Creek Shores sub-appellation). The 2005 season was warmer than average with GDD averaging 1582 across the region. Precipitation in 2005 (426 mm; April to October) was close to average, but the period between May and late July was dry. The 2006 season was relatively cool overall (1430 GDD) with mean precipitation of $472 \mathrm{~mm}$ that was evenly distributed throughout the growing season. Mean daily temperatures were lower than average throughout much of July and August. The 2007 season was drier than the preceding two years, with precipitation averaging $227 \mathrm{~mm}$ across the region, and GDD of 1583. Mean daily temperatures also remained $>20^{\circ} \mathrm{C}$ throughout much of the September.

\section{Spatial variation at the research sites}

Soil texture and composition: Parent material ranged from lacustrine silty clay, reddish hued clay, and loamy textures to reddish hued sandy textures (Table 1). Sand content varied from 26 to $52 \%$ across all sites with the highest content at the Harbour Estate site, followed by the Buis and Reif sites (Fig. 1), while clay ranged from 10 to $23 \%$, with the highest \% clay at the Château des Charmes (CDC) and Buis sites (Fig. 2). OM ranged from 1.0 and $6.0 \%$ (Fig. 3); values $<3.0 \%$ are considered low for mineral soils (Brady and Weil, 2002). CEC ranged from 6 to 53 (mEq/100 g soil) (Hakimi Rezaei, 2009; map data not shown). CEC values $>20$ are typically considered optimal (Brady and Weill, 2002). Soil $\mathrm{pH}$ ranged from 5.5 and 8.0 (map data not shown). Soil $\mathrm{BS}$ as \% Ca (BS-Ca) ranged between 32 to $94 \%$ (map data not shown). It is recommended that BS-Ca be $>75 \%$ (Brady and Weil, 2002). Soil $\mathrm{P}$ varied from 6 and $186 \mathrm{mg} / \mathrm{kg}$ and $\mathrm{K}$ ranged from 101 to $653 \mathrm{mg} / \mathrm{kg}$ (map data not shown). Soil Ca ranged from 514 to $9898 \mathrm{mg} / \mathrm{kg}$ and $\mathrm{Mg}$ ranged from 100 to $716 \mathrm{mg} / \mathrm{kg}$ (map data not shown).

Soil and vine water status 2005 to 2007- temporal stability: Soil moisture in 2005 ranged from 7 to $20 \%$, from 11 to $36 \%$ in 2006, and from 4 to $28 \%$ in 2007 across all sites (Figs. 4 to 6). Lowest and highest soil moisture values, respectively, for each season, were observed at the Hernder and Buis sites (2005), at the Reif and Vieni sites (2006) and at the Harbour Estate and Buis sites (2007) (Table 3). Lowest soil moisture values overall were observed at the Hernder, Reif and Harbour sites. At the Hernder site, lowest mean soil moisture values were $7.3,15.1$ and $6.1 \%$ in 2005, 2006 and 2007, respectively; whereas the highest mean soil moisture values were 13.4, 28.0, and $27.7 \%$. At the Reif site, lowest soil moisture values were 7.6, 11.3 and $8.8 \%$ in 2005 , 2006 and 2007, while highest values were 13.6, 25.6 and $21.3 \%$. Likewise, at the Harbour site low soil moisture values were 9.9, 11.7 and $3.5 \%$ in 2005, 2006 and 2007, while highest values were $13.4,18.7$ and $8.5 \%$. Spatial variation in soil moisture was temporally consistent at nine of ten sites across the 2005 to 2006 vintages (Table 4), and particularly at the Reif site (Fig. 4J,K), and was temporally consistent at all sites from the 2006 to 2007 vintages, particularly Buis (Fig. 4B,C), CDC (Fig. 4E,F), Reif (Fig. 4K,L), Cave Spring (Fig. 5H,I), Henry of Pelham (HOP; 


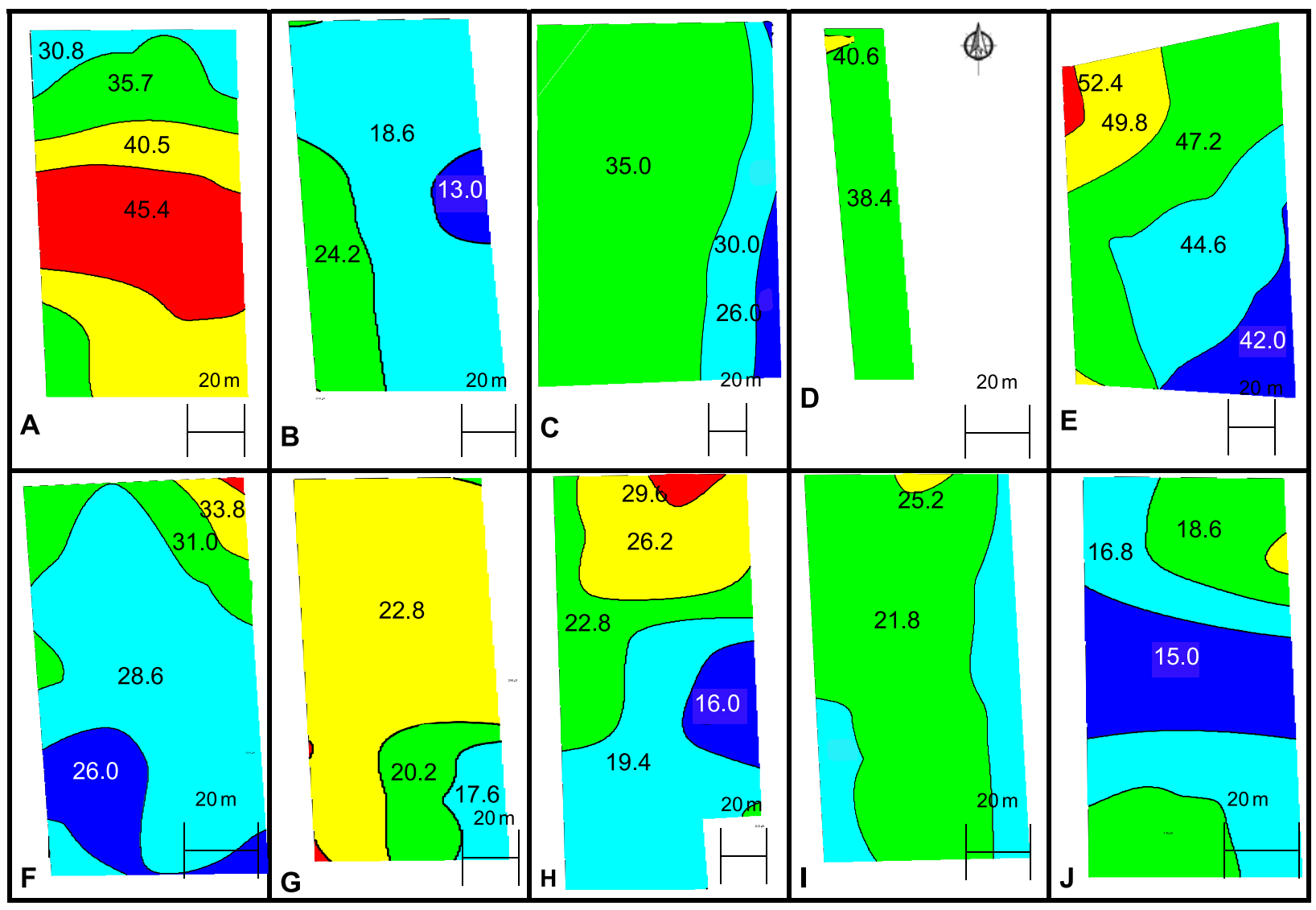

Fig. 1. Spatial distribution of sand at all vineyard blocks, Niagara Peninsula, ON; A: Buis; B: Chateau des Charmes; C: Hernder; D: Reif; E: Harbour Estate; F: George; G: Cave Spring; H: Henry of Pelham; I: Vieni; J: Morrison.



Fig. 2. Spatial distribution of clay at all vineyard blocks, Niagara Peninsula, ON; A: Buis; B: Chateau des Charmes; C: Hernder; D: Reif; E: Harbour Estate; F: George; G: Cave Spring; H: Henry of Pelham; I: Vieni; J: Morrison. 


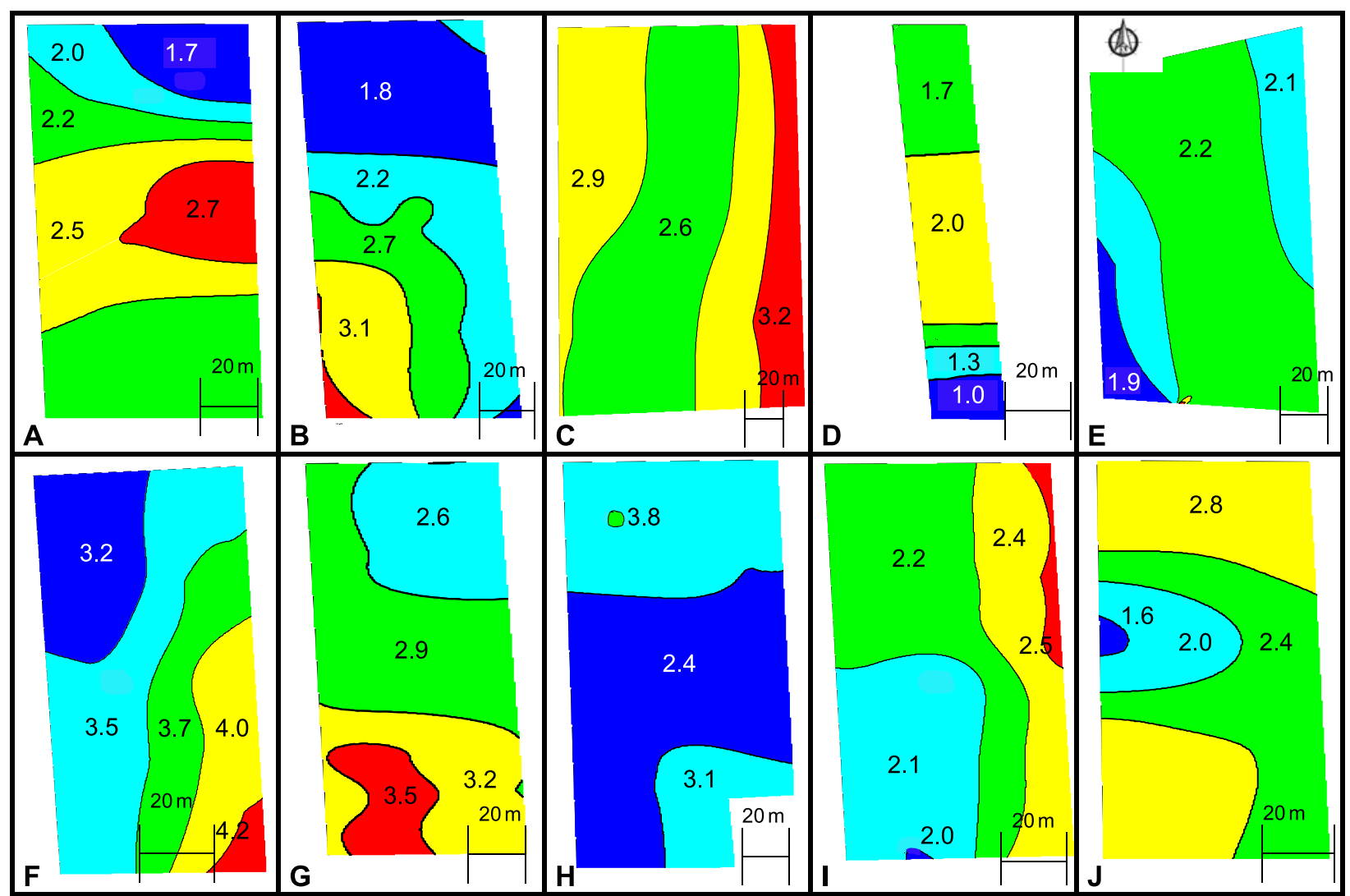

Fig. 3. Spatial distribution of organic matter in all vineyard blocks, Niagara Peninsula, ON; A: Buis; B: Chateau des Charmes; C: Hernder; D: Reif; E: Harbour Estate; F: George; G: Cave Spring; H: Henry of Pelham; I: Vieni; J: Morrison.

Fig. 5K,L), and Morrison (Fig. 6E,F). An examination of temporal consistency between the 2005 and 2007 vintages indicated that eight of ten sites showed significant spatial correlations for soil moisture.

Leaf $\psi$ ranged from -0.80 to $-1.60 \mathrm{MPa}$ in $2005,-0.82$ and -1.60 in 2006 , and -0.93 to $-1.64 \mathrm{MPa}$ in 2007 (Fig. 7 to 9) across all sites. The highest and lowest leaf $\psi$ values, respectively, were observed at Harbour Estate and CDC (2005), at Vieni and Hernder (2006), and at Harbour Estate and CDC (2007) (Table 3). Leaf $\psi$ values were the basis for the water status categories that were tested in terms of yield components and berry composition, and those from which wines were made in 2005 and 2006. Spatial variation in leaf $\psi$ (Table 4; Figs. 7 to 9) was temporally consistent at two sites, 2005 and 2006, at Hernder (Fig. 7G,H) and Harbour (Fig. 8A,B). Three other sites (CDC, Reif, Vieni) had relatively high $r$ values, suggesting temporal stability (Table 4). In 2006 and 2007, temporal stability was apparent at three locations, Reif (Fig. 7K,L), Harbour (Fig. 8B,C), and Cave Spring (Fig. $8 \mathrm{H}, \mathrm{I}$ ). Two other sites (George, HOP) had relatively high $\mathrm{r}$ values, suggesting temporal stability. Comparing the 2005 and 2007 seasons, temporal stability was apparent at two locations, at Vieni (Fig. 9A,C) and Morrison (Fig. 9D,F). Two other sites (Reif, Harbour Estate) had relatively high $r$ values, suggesting temporal stability.

\section{Spatial correlation analysis}

Soil and vine water status- Niagara-on-the-Lake sites: Both soil moisture and leaf $\psi$ displayed spatial correlations with various soil texture, physical properties, and compositional variables (Table 5). At the Buis site, an inverse relationship was apparent between BS and leaf $\psi$ (based upon absolute value) in 2006 (Fig. 4B). At the CDC site, inverse correlative relationships were observed between OM (Fig. 3B), CEC, BS, P, K, and Ca (Hakimi Rezaei, 2009; map data not shown) vs. leaf $\psi$ in 2005 (Fig. 7D), as well as a positive correlation between leaf $\psi$ and $\mathrm{Mg}$ (map data not shown). Soil moisture at the Hernder location in 2006 (Fig. $4 \mathrm{H}$ ) displayed spatial correlations with soil $\mathrm{pH}, \mathrm{BS}, \mathrm{Ca}$, and $\mathrm{Mg}$ (map data not shown). Apparent spatial correlations were also observed between leaf $\psi$ in 2005 and 2006 (Fig. 7G,H); these included positive correlations with \% sand (Fig. 1C), negative ones with CEC (map data not shown), and positive ones (2006; leaf $\psi$ only) with $\mathrm{P}$ and $\mathrm{K}$ (Table 5; map data not shown). At the Reif site, \% sand (Fig. 1D) was inversely correlated with soil moisture (2005, 2006; Fig. 4J,K), as were P and K (map data not shown). A multitude of spatial correlations were also apparent between leaf $\psi(2005,2006$; Fig. 7J,K) vs. OM (Fig. 3D), P, K, and $\mathrm{Mg}$ (map data not shown; all positive correlations) and those involving clay, OM (Fig. 3D), CEC, BS, and Ca (map data not shown; all inverse correlations).

Jordan, Vineland, and Beamsville sites: At the George site, soil moisture in 2005 (Fig. 5D) correlated spatially with P (Table 5; map data not shown), while leaf $\psi$ in 2005 (Fig. 8D) correlated with $\%$ clay (Fig. 2F), OM (Fig. 3F), BS, and Ca (map data not shown). At the Cave Spring location, soil moisture in 2005 and 2006 (Fig. 5G,H) correlated directly with soil P and K (map data not shown), and in 2005 only with soil $\mathrm{pH}, \mathrm{CEC}, \mathrm{BS}$, and $\mathrm{Ca}$ (map data not shown). Inverse relationships were also observed between soil moisture and \% sand (Fig. 1G; both seasons), and Mg (2005 only; map data not shown). Leaf $\psi$ (2005, 2006; Fig. $8 \mathrm{G}, \mathrm{H})$ correlated with \% sand (Fig. 1G; 2006) and inversely 




Fig. 4. Spatial distribution of soil moisture (\%), at four vineyard sites, Niagara Peninsula, ON; A to C: Buis; 2005 (A); 2006 (B); 2007 (C). D to F: Chateau des Charmes; 2005 (D); 2006 (E); 2007 (F). G to I: Hernder; 2005 (G); 2006 (H); 2007 (I). J to L: Reif; 2005 |(J); $2006(\mathrm{~K}) ; 2007$ (L). In each map, the value of each zone represents the corresponding lower limit for that zone. 


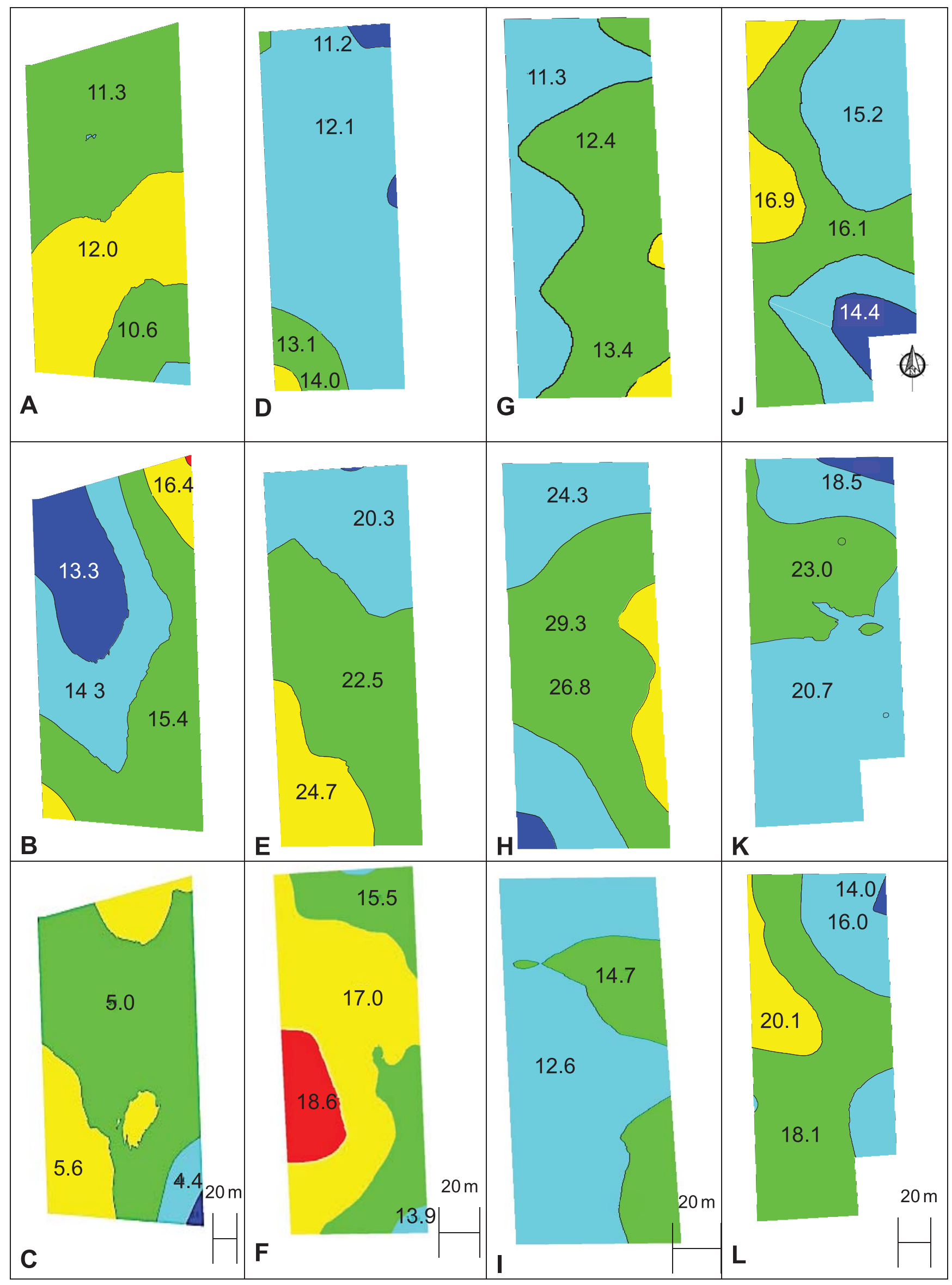

Fig. 5. Spatial distribution of soil moisture (\%), at four vineyard sites, Niagara Peninsula, ON; A to C: Harbour Estate; 2005 (A); 2006 (B); 2007 (C). D to F: George; 2005 (D); 2006 (E); 2007 (F); G to I: Cave Spring 2005 (G); 2006 (H); 2007 (I). J to L: Henry of Pelham; 2005 (J); 2006 (K); 2007 (L). In each map, the value of each zone represents the corresponding lower limit for that zone. 




Fig. 6. Spatial distribution of soil moisture (\%), at two vineyard sites, Niagara Peninsula, ON; A to C: Vieni; 2005 (A); 2006 (B); 2007 (C). D to F: Morrison; 2005 (D); 2006 (E); 2007 (F). In each map, the value of each zone represents the corresponding lower limit for that zone.

with $\mathrm{CEC}, \mathrm{pH}$, and $\mathrm{P}$ (2006; map data not shown). Soil moisture at the HOP location in 2005 (Fig. 5J) displayed direct spatial correlations with \% clay (Fig. $2 \mathrm{H}$ ), $\mathrm{pH}, \mathrm{BS}$, and $\mathrm{Ca}$ (map data not shown). Leaf $\psi$ (2005; Fig. 8J) was spatially correlated with CEC, $\mathrm{pH}, \mathrm{BS}$, and $\mathrm{Ca}$ (map data not shown), and inversely correlated with OM (Fig. 3H). Soil moisture at the Vieni site in 2005 (Fig. 6A) displayed an inverse spatial correlation with OM (Fig. 3I). Leaf $\psi$ in 2005 (Fig. 9A) was spatially correlated with \% sand (Fig. 1I), and inversely correlated with \% clay (Fig. 2I), CEC,
Table 4. Temporal stability of soil moisture and leaf water potential in ten Cabernet Franc vineyards, Niagara Peninsula, Ontario, 2005-2007

\begin{tabular}{|c|c|c|}
\hline Site & Soil moisture & Leaf $\psi$ \\
\hline & 2005 vs. 2006 & \\
\hline Buis & -0.34 & 0.14 \\
\hline Chateau des Charmes & $0.56^{* *}$ & 0.40 \\
\hline Hernder & $0.42 * *$ & $0.83^{* *}$ \\
\hline Reif & $0.84 * *$ & 0.39 \\
\hline George & $0.50 * *$ & -0.28 \\
\hline Henry of Pelham & $0.53 * *$ & 0.03 \\
\hline Cave Spring & $0.45^{* *}$ & 0.22 \\
\hline Harbour Estate & $0.50 * *$ & $0.65^{* *}$ \\
\hline Vieni & $0.59 * *$ & 0.44 \\
\hline \multirow[t]{2}{*}{ Morrison } & $0.52 * *$ & 0.24 \\
\hline & 2006 vs 2007 & \\
\hline Buis & $0.82 * *$ & -0.40 \\
\hline Chateau des Charmes & $0.78 * *$ & -0.09 \\
\hline Hernder & $0.59 * *$ & 0.04 \\
\hline Reif & $0.87 * *$ & $0.84 * *$ \\
\hline George & $0.45^{* *}$ & 0.45 \\
\hline Henry of Pelham & $0.71 * *$ & 0.47 \\
\hline Cave Spring & $0.68 * *$ & $0.50 *$ \\
\hline Harbour Estate & $0.41 * *$ & $0.66^{* *}$ \\
\hline Vieni & $0.62 * *$ & 0.19 \\
\hline \multirow[t]{2}{*}{ Morrison } & $0.71 * *$ & 0.17 \\
\hline & 2005 vs. 2007 & \\
\hline Buis & -0.14 & -0.45 \\
\hline Chateau des Charmes & $0.69 * *$ & -0.05 \\
\hline Hernder & -0.10 & 0.11 \\
\hline Reif & $0.67 * *$ & 0.36 \\
\hline George & $0.44 * *$ & 0.08 \\
\hline Henry of Pelham & $0.59 * *$ & -0.40 \\
\hline Cave Spring & $0.62 * *$ & -0.12 \\
\hline Harbour Estate & $0.57 * *$ & 0.47 \\
\hline Vieni & $0.66 * *$ & $0.66^{* *}$ \\
\hline Morrison & $0.55^{* *}$ & $0.65^{* *}$ \\
\hline
\end{tabular}

*,**: Significant at $P \leq 0.05$ or 0.01 , respectively. Significant inverse correlations are not indicated.

$\mathrm{pH}, \mathrm{BS}, \mathrm{P}, \mathrm{K}, \mathrm{Ca}$, and $\mathrm{Mg}$ (map data not shown). Those spatial correlations at the Morrison location involving soil moisture (Fig. 6D,E) included relationships with CEC (2006), soil pH (2006), BS (2005, 2006), and Ca (2006)(all map data not shown); inverse relationships included those with OM (Fig. 3J; 2006), P (map data not shown; 2005), and K (map data not shown; 2005, 2006). Leaf $\psi$ in 2005 (Fig. 6D) was directly spatially correlated with BS and Ca (map data not shown), and inversely with $\mathrm{P}, \mathrm{K}$, and $\mathrm{Mg}$ (map data not shown).

\section{Soil texture and composition}

Niagara-on-the-Lake sites: In terms of soil texture and composition, there were many noteworthy spatial correlative relationships in the ten vineyards (Table 5). Soil textural components were associated with numerous variables, and those relationships with OM may have had implications for soil and vine water status. At the Buis site, \% sand (Fig. 1A) showed high spatial correlations with OM (Fig. 3A), P, and K (map data not shown) and was inversely correlated with \% clay (Fig. 2A), soil $\mathrm{pH}, \mathrm{BS}, \mathrm{Ca}$, and $\mathrm{Mg}$ (map data not shown). Percent clay (Fig. 2A) showed positive spatial correlations with $\mathrm{CEC}$, soil $\mathrm{pH}, \mathrm{Ca}$, and $\mathrm{Mg}$ (map data not shown) but was negatively correlated with OM (Fig. 3A), P, and K (map data not shown). An example of maps from this location comparing spatial relationships between soil moisture, \% clay, CEC, soil $\mathrm{Ca}, \mathrm{BS}, \mathrm{K}$ and $\mathrm{Mg}$ is shown in Fig. 


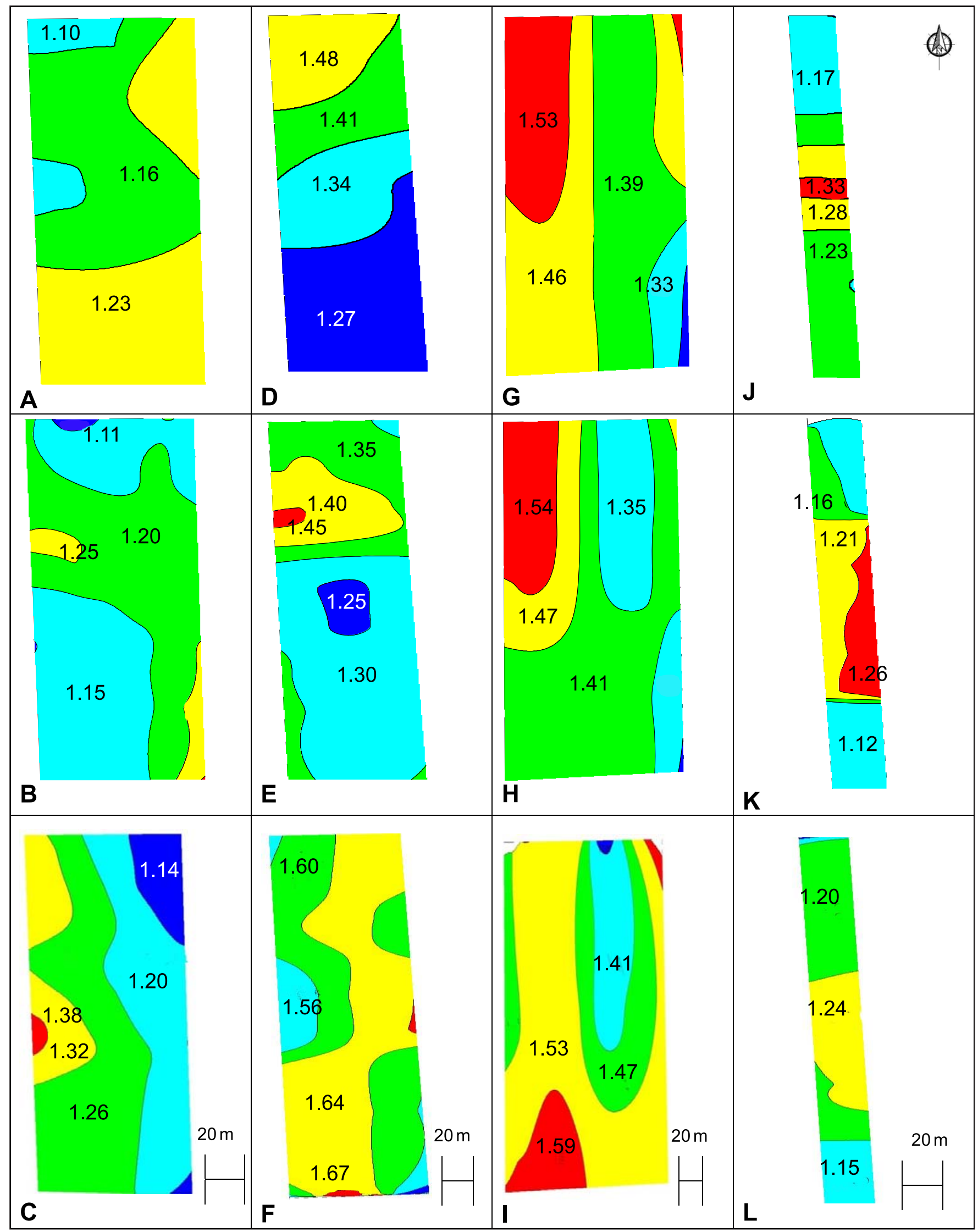

Fig. 7. Spatial distribution of leaf water potential (-MPa) at four vineyard sites, Niagara Peninsula, ON; A to C: Buis; 2005 (A); 2006 (B); 2007 (C). D to F: Chateau des Charmes; 2005 (D); 2006 (E); 2007 (F). G to I: Hernder; 2005 (G); 2006 (H); 2007 (I). J to L: Reif; $2005(\mathrm{~J}) ; 2006(\mathrm{~K}) ; 2007$ (L) In each map, the value of each zone represents the corresponding lower limit for that zone. 


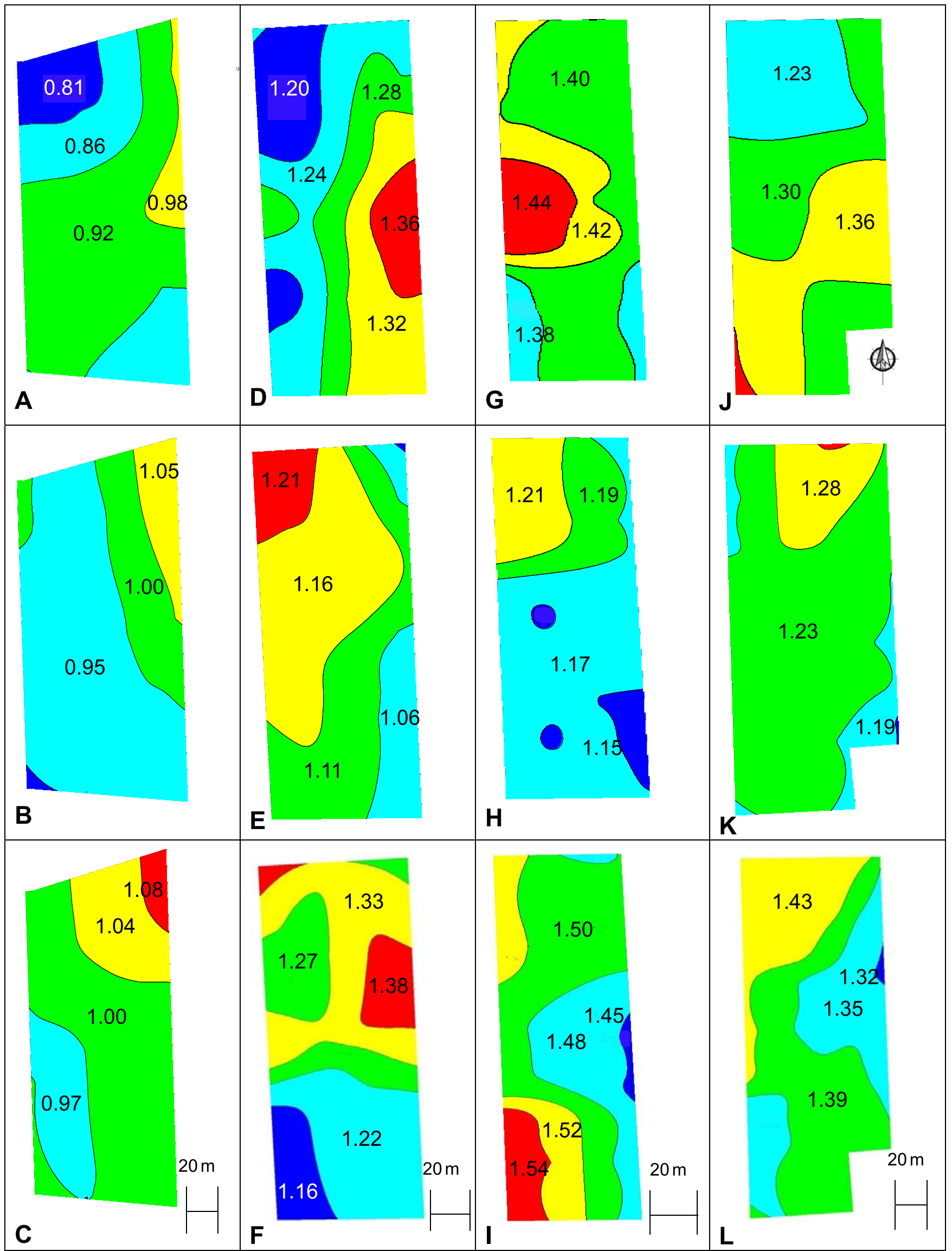

Fig. 8. Spatial distribution of leaf water potential (-MPa) at four vineyard sites, Niagara Peninsula, ON; A to C: Harbour Estate; 2005 (A); 2006 (B); 2007 (C). D to F: George; 2005 (D); 2006 (E); 2007 (F). G to I: Cave Spring; 2005 (G); 2006 (H); 2007 (I). J to L: Henry of Pelham; 2005 (J); 2006 (K); 2007 (L).In each map, the value of each zone represents the corresponding lower limit 


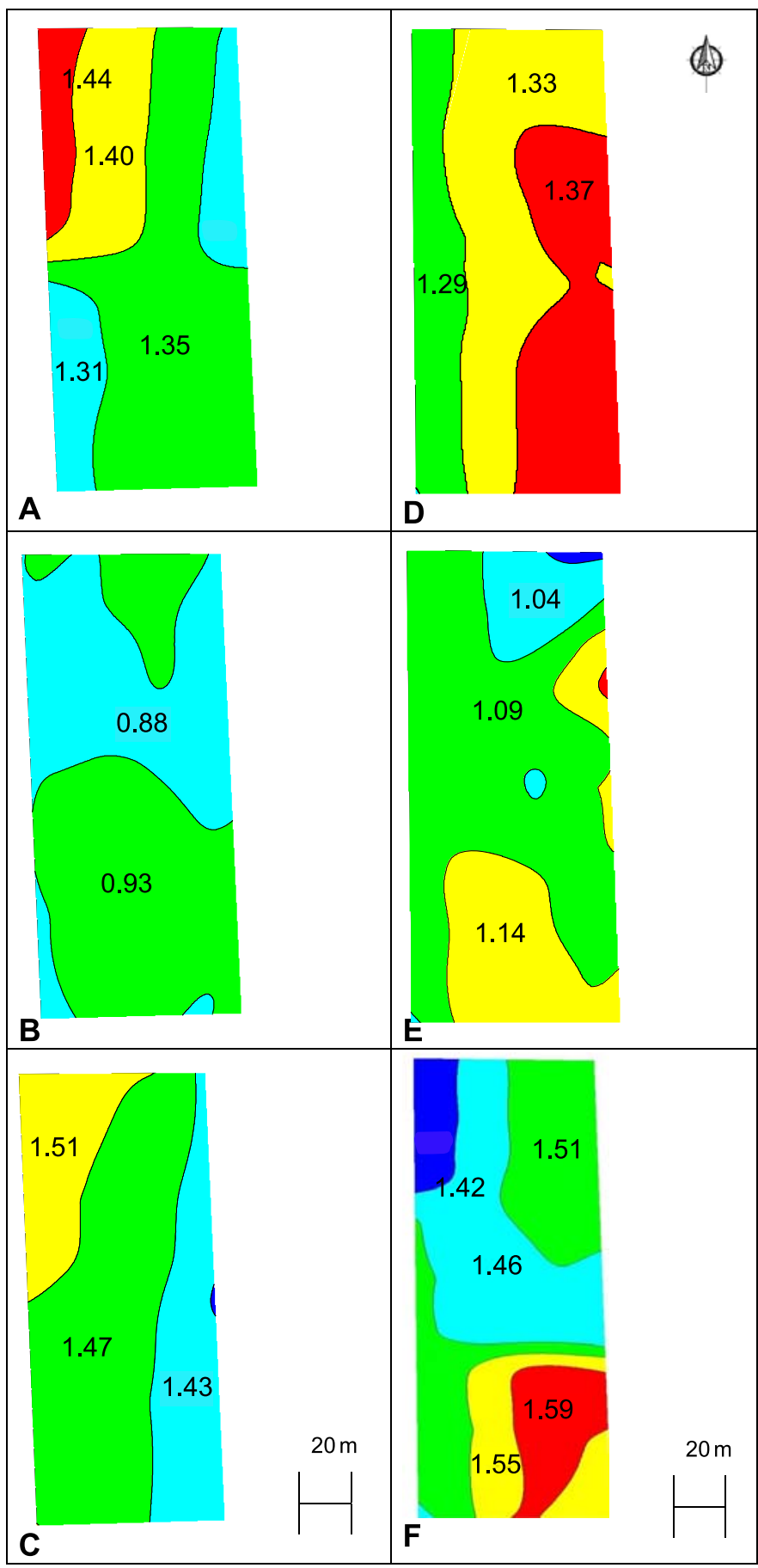

Fig. 9. Spatial distribution of leaf $\psi(-\mathrm{MPa})$ at two vineyard sites, Niagara Peninsula, ON; A to C: Vieni; 2005 (A); 2006 (B); 2007 (C). D to F: Morrison; 2005 (D); 2006 (E); 2007 (F). In each map, the value of each zone represents the corresponding lower limit for that zone.

10A-E. At the CDC site, \% sand (Fig. 1B) was correlated spatially with OM (Fig. 3B) and inversely correlated with \% clay (Fig. 2B) and soil moisture in 2005 (Fig. 4D). An example of maps from this location illustrating spatial relationships between soil moisture, $\%$ clay, CEC, soil Ca, BS, $\mathrm{K}$ and Mg is shown in Fig. 10F-J. At the Hernder site, sand was inversely correlated spatially with OM (Fig. 3C). At the Reif site, \% clay (Fig. 2D) was positively correlated spatially with $\mathrm{CEC}$, soil $\mathrm{pH}, \mathrm{BS}$, and $\mathrm{Ca}$ (map data not shown), but was negatively correlated with OM (Fig. 3D), $\mathrm{P}, \mathrm{K}$, and $\mathrm{Mg}$ (map data not shown). At all sites, several spatial correlations involved soil OM (Fig. 3A-D), CEC, soil pH, and
$\mathrm{BS}$, as well as $\mathrm{P}, \mathrm{K}, \mathrm{Ca}$, and $\mathrm{Mg}$ (map data not shown).

Jordan, Vineland, and Beamsville sites: Spatial correlation analysis at the Harbour site showed that \% clay was negatively correlated with \% sand (Table 5; Fig. 1E, S3E). At the George site, $\%$ sand (Fig. 1F) was highly negatively correlated spatially with a multitude of variables including \% clay (Fig. 2F), OM (Fig. 3F), soil pH, BS, K, Ca, and Mg (map data not shown). As expected, \% clay spatial relationships were inverse to those with \% sand. An example of maps from this location comparing spatial relationships between soil moisture, \% clay, CEC, Ca, BS, $\mathrm{K}$ and $\mathrm{Mg}$ is shown in Fig. $11 \mathrm{~A}-\mathrm{E}$. At the Cave Spring site, \% sand (Fig. 1G) was negatively correlated spatially with \% clay (Fig. 2G), CEC, pH, BS, P, K, and Ca (map data not shown), and positively correlated with $\mathrm{Mg}$ (map data not shown). An example of maps from this site comparing spatial relationships between soil moisture, \% clay, $\mathrm{CEC}, \mathrm{Ca}, \mathrm{BS}, \mathrm{K}$ and $\mathrm{Mg}$ is shown in Fig. 11F-J. At the HOP site, $\%$ sand (Fig. $1 \mathrm{H}$ ) was positively correlated spatially with $\mathrm{OM}$ (Fig. $3 \mathrm{H}$ ) and $\mathrm{P}$ (map data not shown) and negatively correlated with $\%$ clay (Fig. $2 \mathrm{H}$ ), pH, CEC, BS, and $\mathrm{Ca}$ (map data not shown). As expected, relationships involving $\%$ clay were inverse to those with sand, with the exception of a lack of correlation with P. At the Vieni site, \% sand (Fig. 1I) was negatively correlated spatially with \% clay (Fig. 2I), OM (Fig. 3I), $\mathrm{pH}, \mathrm{CEC}, \mathrm{BS}, \mathrm{Ca}$, and $\mathrm{Mg}$ (map data not shown). Relationships involving \% clay were the inverse of those with \% sand, with the exception of a lack of correlation with OM. At the Morrison site, sand (Fig. 1J) was spatially correlated with OM (Fig. 3J) and P (map data not shown) and inversely with \% clay (Fig. 2J) and $\mathrm{pH}$ (map data not shown). At all sites, many spatial relationships involved OM (Fig. 3F-J), pH, CEC, and BS, as well as P, K, Ca, and $\mathrm{Mg}$ (map data not shown).

Correlation analysis: Correlation analysis of soil factors for all sites in 2005 indicated that leaf $\psi$ was positively correlated with \% clay, $\mathrm{OM}$, soil $\mathrm{pH}, \mathrm{BS}, \mathrm{Ca}$ and $\mathrm{Mg}$, and was negatively correlated with $\%$ sand (Table 6). Soil moisture had positive correlation with $\mathrm{CEC}, \mathrm{BS}$, and $\mathrm{Ca}$, but was negatively correlated with $\mathrm{K}$. Mg was positively correlated with \% clay, $\mathrm{OM}, \mathrm{CEC}, \mathrm{pH}, \mathrm{BS}$, and $\mathrm{Ca}$, but was negatively correlated with $\%$ sand, $\mathrm{P}$ and $\mathrm{K}$. Ca was positively correlated with \% clay, CEC, $\mathrm{pH}$ and $\mathrm{BS}$, and was negatively correlated with $\%$ sand; $\mathrm{K}$ was positively correlated with $\%$ sand and $\mathrm{P}$, and negatively correlated with BS; P was negatively correlated with $\%$ clay and BS but had a positive correlation with \% sand. BS had a positive correlation with \% clay, CEC and $\mathrm{pH}$, and was negatively correlated with $\%$ sand. Soil $\mathrm{pH}$ was positively correlated with CEC and \% clay and negatively with $\%$ sand; OM and CEC both negatively correlated with \% sand and positively with $\%$ clay; $\%$ clay negatively correlated with $\%$ sand. In 2006 and 2007, soil moisture was negatively correlated with \% sand and was positively correlated with \% clay, CEC, $\mathrm{pH}, \mathrm{BS}, \mathrm{Ca}$ and $\mathrm{Mg}$, while leaf $\psi$ correlated negatively with $\%$ sand (2007 only), and positively with \% clay, CEC, pH, BS, K, $\mathrm{Ca}$ and $\mathrm{Mg}$ (2007 only).

Principal components analysis: PCA conducted on the 2005 leaf $\psi$, soil moisture, and soil composition data explained 59.6 $\%$ of the variability in the data in the first two dimensions (Fig. 12A). PC1 accounted for $45.0 \%$ of the variability and was most heavily loaded in the positive direction with soil moisture, leaf $\psi, \%$ clay, soil $\mathrm{pH}, \mathrm{OM}, \mathrm{CEC}, \mathrm{BS}, \mathrm{Ca}$, and $\mathrm{Mg}$. The small 


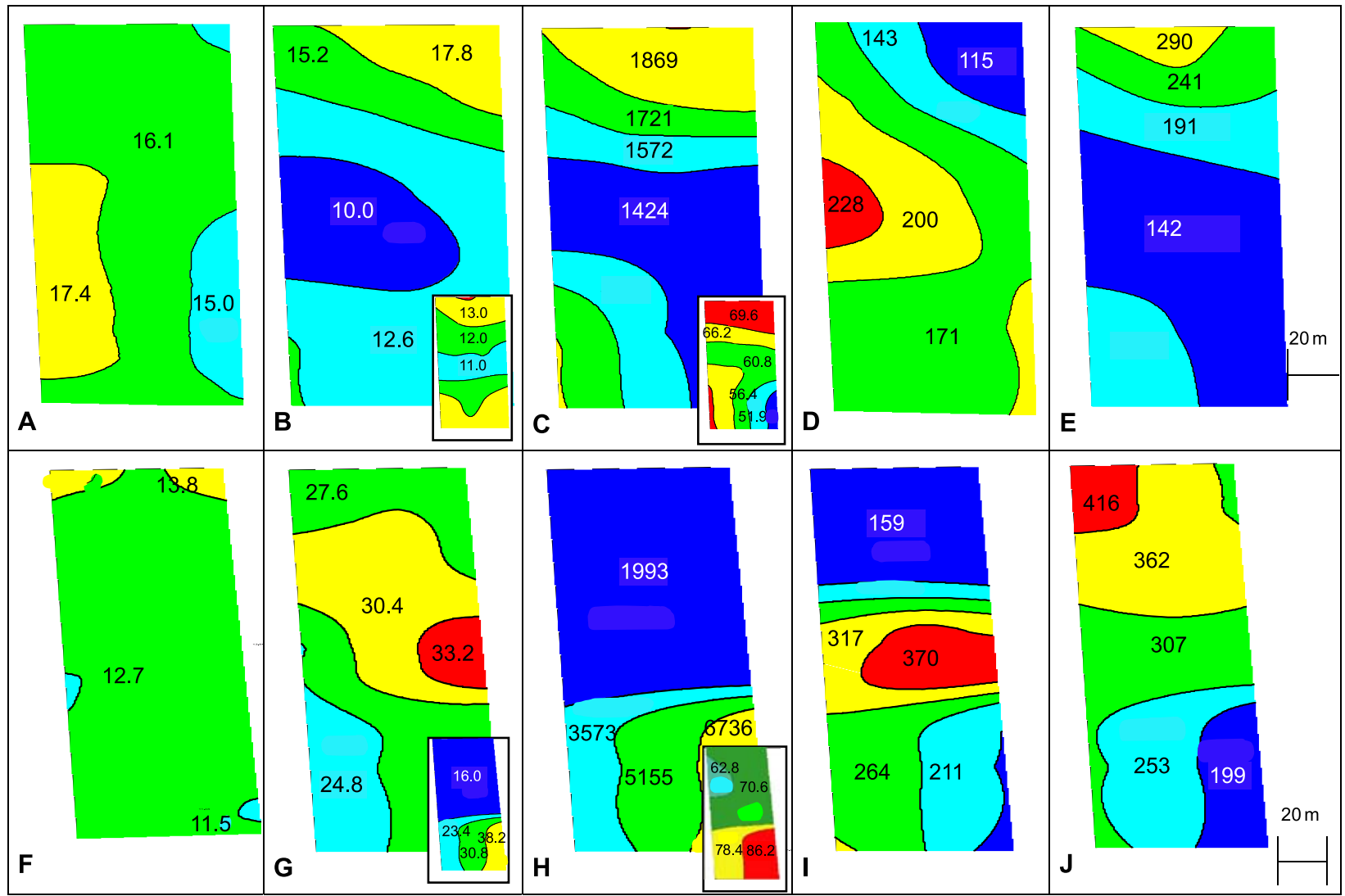

Fig. 10. Spatial variation in two east Niagara Cabernet Franc vineyards. A to E: Buis Vineyard; F to J: Chateau des Charmes.

A, F: Soil moisture (\%); B, G: Clay (\%), inset: cation exchange capacity (mEq/100 mL); C, H: Soil Ca (mg/kg), inset: base saturation (\% as Ca); D, I: Soil K (mg/K); E, J: Soil Mg ( $\mathrm{mg} / \mathrm{kg})$. Values represent the lower limit within each zone.

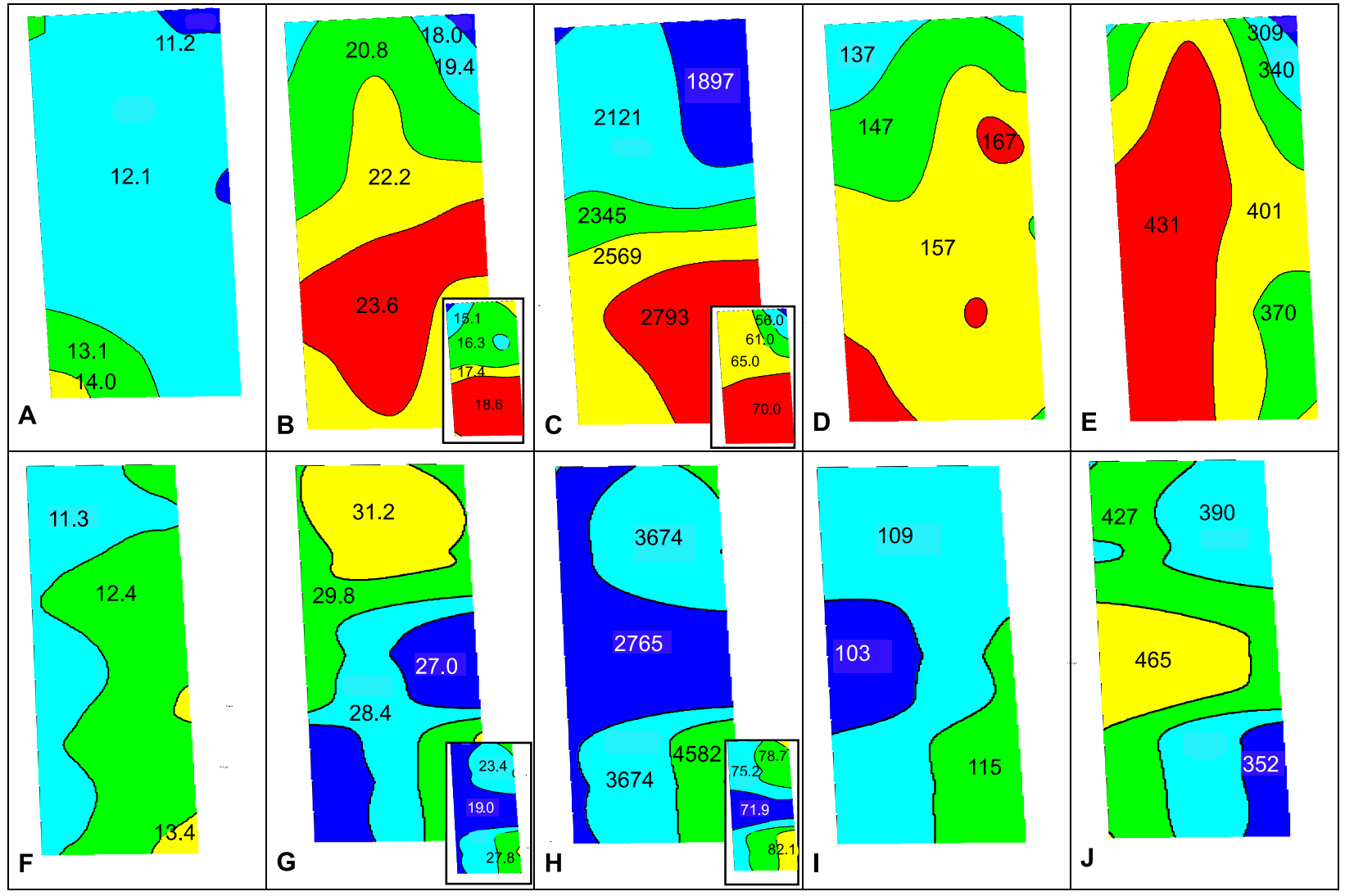

Fig. 11. Spatial variation in two west Niagara Cabernet Franc vineyards. A to E: George Vineyard; F to J: Cave Spring Vineyard.

A, F: Soil moisture (\%); B, G: Clay (\%), inset: cation exchange capacity (mEq/100 mL); C, H: Soil Ca (mg/kg), inset: base saturation (\% as Ca); D, I: Soil K (mg/K); E, J: Soil Mg (mg/kg). Values represent the lower limit within each zone. 


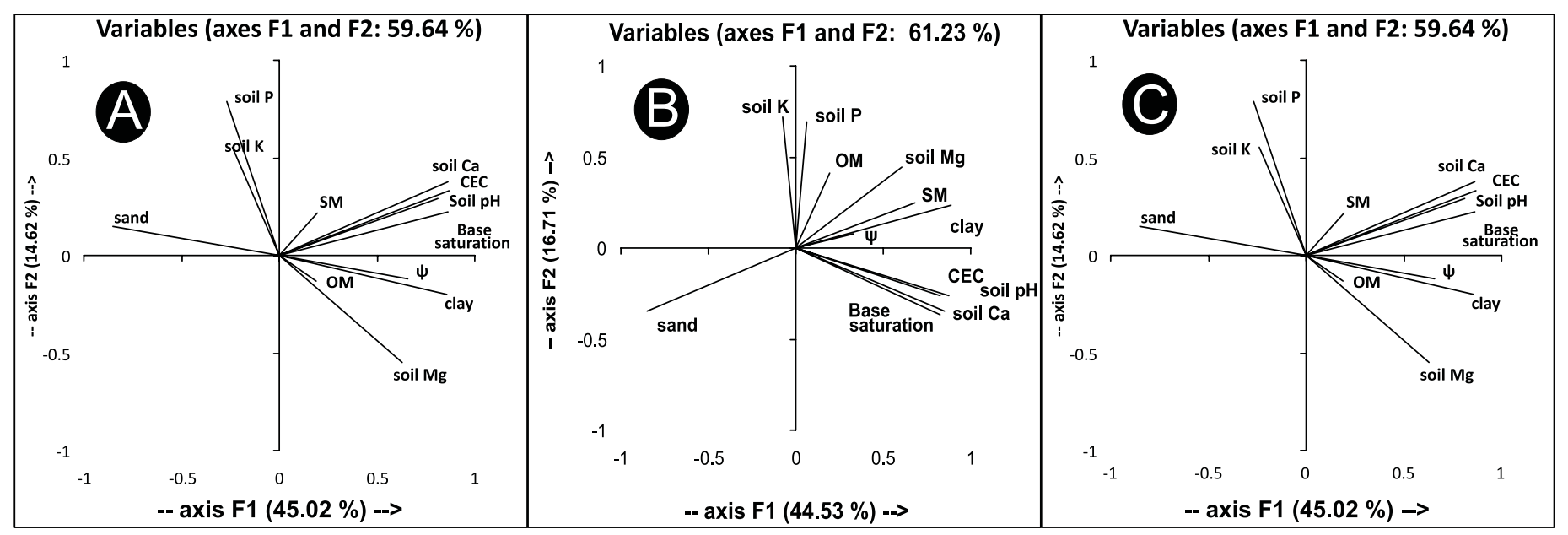

Fig. 12. Principal components analysis of leaf $\psi$, soil moisture, and soil composition data from ten Cabernet Franc sites, Niagara Peninsula, ON, A: 2005. Percentages of variation represented by the data set are 45.0\% (PC1) and 14.6\% (PC2); B: 2006. Percentages of variation represented by the data set are $44.5 \%$ (PC1) and 16.7 (PC2); C: 2007. Percentages of variation represented by the data set are $43.8 \%$ (PC1) and $17.1 \%$ (PC2).

angles between the eigenvectors suggested that these variables were closely correlated. Percent sand was heavily loaded in the negative direction. PC2 accounted for $14.6 \%$ of the variability and was most heavily loaded in the positive direction with $\mathrm{P}$ and
K. The third PC explained another $13.9 \%$ of the variation (data not shown). PCA conducted on these data in 2006 explained 61.2 $\%$ of the variability in the data in the first two dimensions (Fig. 12B). PC1 accounted for $45.0 \%$ of the variability and was most

Table 5. Spatial correlations 2005-2007—soil composition, soil physical properties, soil moisture, leaf water potential. Abbreviations: OM: organic matter; CEC: cation exchange capacity; BS: base saturation; SM: soil moisture

\begin{tabular}{|c|c|c|c|c|c|c|c|c|c|c|}
\hline & Sand & Clay & Soil pH & Soil OM & CEC & BS-Ca & $\mathrm{P}$ & $\mathrm{K}$ & $\mathrm{Ca}$ & $\mathrm{Mg}$ \\
\hline \multicolumn{11}{|c|}{ Buis } \\
\hline Clay & $-0.88 * *$ & & & & & & & & & \\
\hline Soil pH & $-0.74 * *$ & $0.76^{* *}$ & & & & & & & & \\
\hline Soil OM & $0.73 * *$ & $-0.82 * *$ & $-0.66 * *$ & & & & & & & \\
\hline CEC & -0.48 & $0.55^{*}$ & 0.39 & -0.44 & & & & & & \\
\hline BS-Ca & $-0.59 *$ & 0.43 & $0.76^{* *}$ & -0.29 & -0.10 & & & & & \\
\hline $\mathrm{P}$ & $0.50 *$ & $-0.68 * *$ & $-0.65 * *$ & $0.70 * *$ & -0.08 & -0.27 & & & & \\
\hline K & $0.64 * *$ & $-0.85^{* *}$ & $-0.71 * *$ & $0.70 * *$ & -0.30 & -0.44 & $0.74 * *$ & & & \\
\hline $\mathrm{Ca}$ & $-0.82 * *$ & $0.79 * *$ & $0.91 * *$ & $-0.61 * *$ & $0.63 * *$ & $0.70 * *$ & -0.37 & $-0.64 * *$ & & \\
\hline $\mathrm{Mg}$ & $-0.67 * *$ & $0.73 * *$ & $0.85 * *$ & $-0.61 * *$ & $0.63 * *$ & 0.43 & $-0.62 * *$ & $-0.64 * *$ & $0.82 * *$ & \\
\hline SM 05 & 0.17 & -0.37 & 0.13 & 0.28 & -0.10 & 0.34 & 0.40 & 0.45 & 0.13 & -0.07 \\
\hline SM 06 & -0.33 & 0.42 & 0.21 & -0.45 & $0.75 * *$ & -0.02 & 0.02 & -0.35 & 0.45 & 0.38 \\
\hline SM 07 & -0.19 & 0.25 & 0.08 & -0.40 & $0.60 * *$ & -0.15 & 0.08 & -0.22 & 0.28 & 0.27 \\
\hline Leaf $\psi 05$ & -0.01 & 0.06 & -0.22 & 0.07 & 0.01 & -0.01 & 0.33 & -0.23 & -0.02 & -0.39 \\
\hline Leaf $\psi 06$ & 0.28 & -0.21 & -0.48 & 0.14 & 0.01 & $-0.71 * *$ & 0.04 & 0.22 & $-0.51 *$ & -0.34 \\
\hline Leaf $\psi 07$ & 0.12 & -0.48 & -0.14 & 0.33 & -- & 0.22 & $0.53 *$ & $0.67 * *$ & -0.07 & -0.17 \\
\hline \multicolumn{11}{|c|}{ Chateau des Charmes } \\
\hline Clay & $-0.79 * *$ & & & & & & & & & \\
\hline Soil pH & -0.08 & -0.43 & & & & & & & & \\
\hline Soil OM & $0.57^{*}$ & -0.47 & 0.20 & & & & & & & \\
\hline CEC & -0.10 & -0.26 & $0.79 * *$ & 0.03 & & & & & & \\
\hline $\mathrm{BS}-\mathrm{Ca}$ & -0.16 & -0.31 & $0.96 * *$ & 0.17 & $0.89 * *$ & & & & & \\
\hline $\mathrm{P}$ & 0.20 & -0.30 & $0.51 *$ & $0.77 * *$ & $0.56^{*}$ & $0.62 * *$ & & & & \\
\hline K & 0.25 & 0.07 & -0.25 & $0.66^{* *}$ & -0.20 & -0.18 & $0.50 *$ & & & \\
\hline $\mathrm{Ca}$ & -0.12 & -0.25 & $0.83 * *$ & 0.05 & $0.99^{* *}$ & $0.92 * *$ & $0.58^{*}$ & -0.19 & & \\
\hline $\mathrm{Mg}$ & 0.18 & 0.15 & $-0.78 * *$ & -0.31 & $-0.77 * *$ & $-0.86^{* *}$ & $-0.76^{* *}$ & -0.09 & $-0.80 * *$ & \\
\hline SM 05 & $-0.65 * *$ & 0.40 & 0.07 & -0.38 & -0.07 & 0.08 & -0.20 & -0.30 & -0.04 & -0.04 \\
\hline SM 06 & -0.30 & 0.31 & -0.15 & -0.14 & -0.42 & -0.23 & -0.36 & -0.03 & -0.40 & 0.38 \\
\hline SM 07 & -0.48 & $0.53 *$ & -0.25 & -0.22 & -0.34 & -0.23 & -0.28 & 0.03 & -0.32 & 0.22 \\
\hline Leaf $\psi 05$ & 0.07 & 0.07 & -0.41 & $-0.50 *$ & $-0.55^{*}$ & $-0.56^{*}$ & $-0.84 * *$ & $-0.55^{*}$ & $-0.57 *$ & $0.72 * *$ \\
\hline Leaf $\psi 06$ & 0.30 & -0.15 & -0.32 & -0.13 & -0.19 & -0.35 & -0.28 & -0.43 & -0.22 & 0.31 \\
\hline Leaf $\psi 07$ & -0.42 & $0.59 *$ & -0.18 & 0.21 & -0.24 & -0.14 & 0.15 & 0.21 & -0.23 & 0.05 \\
\hline
\end{tabular}


Table 5 contd.

\begin{tabular}{|c|c|c|c|c|c|c|c|c|c|c|}
\hline & Sand & Clay & Soil pH & Soil OM & CEC & $\mathrm{BS}-\mathrm{Ca}$ & $\mathrm{P}$ & $\mathrm{K}$ & $\mathrm{Ca}$ & $\mathrm{Mg}$ \\
\hline \multicolumn{11}{|c|}{ Hernder } \\
\hline Clay & 0.45 & & & & & & & & & \\
\hline Soil $\mathrm{pH}$ & -0.46 & -0.23 & & & & & & & & \\
\hline Soil OM & $-0.60 * *$ & -0.34 & $-0.56^{*}$ & & & & & & & \\
\hline CEC & -0.22 & -0.22 & 0.36 & -0.03 & & & & & & \\
\hline BS-Ca & 0.02 & -0.23 & $0.98 * *$ & $-0.53 *$ & 0.33 & & & & & \\
\hline $\mathrm{P}$ & 0.11 & 0.21 & -0.42 & 0.47 & $-0.54^{*}$ & -0.38 & & & & \\
\hline K & 0.17 & 0.04 & -0.26 & 0.43 & $-0.52 *$ & -0.25 & $0.92 * *$ & & & \\
\hline $\mathrm{Ca}$ & -0.03 & -0.03 & $0.93 * *$ & -0.43 & $0.65^{* *}$ & $0.93 * *$ & -0.47 & -0.35 & & \\
\hline $\mathrm{Mg}$ & -0.12 & -0.4 & $0.60 * *$ & -0.16 & 0.12 & $0.69 * *$ & 0.06 & 0.15 & $0.59 *$ & \\
\hline SM 05 & 0.21 & 0.18 & 0.31 & -0.13 & -0.24 & 0.29 & 0.02 & 0.15 & 0.14 & 0.18 \\
\hline SM 06 & -0.33 & -0.25 & $0.60 * *$ & -0.09 & 0.03 & $0.66^{* *}$ & -0.05 & 0.01 & $0.54 *$ & $0.57^{*}$ \\
\hline SM 07 & $-0.50 *$ & 0.07 & -0.03 & 0.03 & 0.29 & -0.04 & -0.14 & -0.29 & 0.14 & -0.02 \\
\hline Leaf $\psi 05$ & $0.58 *$ & 0.25 & -0.23 & -0.12 & $-0.64 * *$ & -0.33 & 0.27 & 0.36 & -0.48 & -0.36 \\
\hline Leaf $\psi 06$ & $0.52 *$ & 0.38 & -0.09 & -0.02 & $-0.75 * *$ & -0.13 & $0.60 * *$ & $0.68 * *$ & -0.35 & -0.07 \\
\hline Leaf $\psi 07$ & -0.31 & 0.23 & -0.03 & 0.06 & -0.14 & -0.1 & -0.33 & -0.43 & -0.1 & -0.3 \\
\hline \multicolumn{11}{|c|}{ Reif } \\
\hline Clay & 0.20 & & & & & & & & & \\
\hline Soil pH & 0.09 & $0.98 * *$ & & & & & & & & \\
\hline Soil OM & -0.14 & $-0.93 * *$ & $-0.94 * *$ & & & & & & & \\
\hline CEC & -0.03 & $0.90 * *$ & $0.94 * *$ & $-0.86^{* *}$ & & & & & & \\
\hline $\mathrm{BS}-\mathrm{Ca}$ & 0.03 & $0.96 * *$ & $0.99 * *$ & $-0.93 * *$ & $0.98 * *$ & & & & & \\
\hline $\mathrm{P}$ & -0.16 & $-0.75^{* *}$ & $-0.73 * *$ & $0.90 * *$ & $-0.58 *$ & $-0.71 * *$ & & & & \\
\hline K & -0.49 & $-0.89 * *$ & $-0.82 * *$ & $0.81 * *$ & $-0.64 * *$ & $-0.76^{* *}$ & $0.76 * *$ & & & \\
\hline $\mathrm{Ca}$ & -0.03 & $0.91 * *$ & $0.95^{* *}$ & $-0.87 * *$ & $0.99 * *$ & $0.98 * *$ & $-0.60 * *$ & $-0.65 * *$ & & \\
\hline $\mathrm{Mg}$ & 0.24 & $-0.62 * *$ & $-0.66 * *$ & $0.81 * *$ & $-0.65 * *$ & $-0.71 * *$ & $0.87 * *$ & 0.45 & $-0.66^{* *}$ & \\
\hline SM 05 & $-0.57^{*}$ & -0.35 & -0.29 & 0.43 & -0.09 & -0.22 & $0.57 *$ & $0.57 *$ & -0.1 & 0.26 \\
\hline SM 06 & $-0.55^{*}$ & -0.38 & -0.27 & 0.38 & -0.06 & -0.21 & $0.61 * *$ & $0.68 * *$ & -0.08 & 0.29 \\
\hline SM 07 & $-0.50 *$ & -0.31 & -0.21 & 0.32 & 0.02 & -0.15 & $0.59 *$ & $0.65 * *$ & 0.001 & 0.27 \\
\hline Leaf $\psi 05$ & 0.23 & -0.22 & -0.25 & $0.52 *$ & -0.21 & -0.29 & $0.75^{* *}$ & 0.14 & -0.22 & $0.86^{* *}$ \\
\hline Leaf $\psi 06$ & -0.07 & $-0.80 * *$ & $-0.75 * *$ & $0.80 * *$ & $-0.58^{*}$ & $-0.71 * *$ & $0.86 * *$ & $0.85 * *$ & $-0.60 * *$ & $0.72 * *$ \\
\hline Leaf $\psi 07$ & -0.11 & $-0.94 * *$ & $-0.92 * *$ & $0.95 * *$ & $-0.81 * *$ & $-0.90 * *$ & $0.88 * *$ & $0.87 * *$ & $-0.83 * *$ & $0.80 * *$ \\
\hline
\end{tabular}

heavily loaded in the positive direction with soil moisture, leaf $\psi$, $\%$ clay, $\mathrm{pH}, \mathrm{CEC}, \mathrm{BS}, \mathrm{Ca}$, and $\mathrm{Mg}$. Again, small angles between the eigenvectors suggested that these variables were closely correlated. Percent sand was again heavily loaded in the negative direction. PC2 accounted for $16.7 \%$ of the variability and was most heavily loaded in the positive direction with OM, P, and $\mathrm{K}$. The third PC explained another $11.6 \%$ of the variation (data not shown). PCA conducted on these data in 2007 explained 60.9 $\%$ of the variability in the data in the first two dimensions (Fig. 12C). PC1 accounted for $43.8 \%$ of the variability and as in 2005 and 2006 was most heavily loaded in the positive direction with soil moisture, leaf $\psi, \%$ clay, $\mathrm{pH}, \mathrm{CEC}, \mathrm{BS}, \mathrm{Ca}$, and Mg. Small angles between the eigenvectors suggested that these variables were closely correlated. Percent sand was once again heavily loaded in the negative direction. PC2 accounted for $17.1 \%$ of the variability and was most heavily loaded in the positive direction with OM, P, and $\mathrm{K}$. The third PC explained another $10.5 \%$ of the variation (data not shown).

\section{Discussion}

This investigation was initiated with the purpose of identifying the major factors that contribute to the terroir effect in the vineyards of the Niagara Peninsula in Ontario. It was hypothesized, consistently with Seguin (1986), that the main factors might be soil-texture based. It was also hypothesized, consistent with van Leeuwen and Seguin (1994) and van Leeuwen et al. (2004) that the terroir effect would be strongly based upon soil moisture, vine water status, or both. These hypotheses were for the most part proven, primarily with respect to soil moisture. In the majority of situations, distinct spatial patterns in soil texture, soil moisture, and leaf $\psi$ were demonstrated. Moreover, the spatial patterns were in most cases (soil moisture) and occasionally (leaf $\psi$ ) temporally stable, and any temporal variations in their spatial patterns were likely influenced by the volatile precipitation patterns that are typical of the region. Finally, there were clear spatial correlations between soil moisture, leaf $\psi$, and many soil physical and composition variables, including soil texture (\% sand and clay), soil $\mathrm{pH}, \mathrm{OM}, \mathrm{CEC}, \mathrm{BS}, \mathrm{P}, \mathrm{K}, \mathrm{Ca}$, and $\mathrm{Mg}$.

\section{Spatial variability}

Soil moisture: Based on the range of soil moistures obtained at each site and in each year, it was possible to identify soil water status zones at each vineyard block; therefore the part of hypothesis that temporally stable soil water status zones could be identified was supported by the data in all three years. 
Table 5 contd.

\begin{tabular}{|c|c|c|c|c|c|c|c|c|c|c|}
\hline & Sand & Clay & Soil pH & Soil OM & $\mathrm{CEC}$ & BS-Ca & $\mathrm{P}$ & $\mathrm{K}$ & $\mathrm{Ca}$ & $\mathrm{Mg}$ \\
\hline \multicolumn{11}{|c|}{ Harbour } \\
\hline Clay & $-0.91 * *$ & & & & & & & & & \\
\hline Soil $\mathrm{pH}$ & $0.72 * *$ & $-0.56 * *$ & & & & & & & & \\
\hline Soil OM & -0.18 & 0.26 & 0.08 & & & & & & & \\
\hline $\mathrm{CEC}$ & $-0.60 * *$ & $0.60 * *$ & -0.42 & $0.47^{*}$ & & & & & & \\
\hline BS-Ca & $-0.70 * *$ & $0.66^{* *}$ & -0.16 & $0.54^{*}$ & $0.46^{*}$ & & & & & \\
\hline $\mathrm{P}$ & $0.73 * *$ & $-0.68 * *$ & $0.46^{*}$ & -0.01 & -0.10 & $-0.72 * *$ & & & & \\
\hline $\mathrm{K}$ & 0.22 & -0.18 & 0.23 & -0.07 & 0.39 & -0.27 & $0.64 * *$ & & & \\
\hline $\mathrm{Ca}$ & $-0.76^{* *}$ & $0.71 * *$ & -0.31 & $0.50^{*}$ & $0.76^{* *}$ & $0.92 * *$ & $-0.56 * *$ & 0.03 & & \\
\hline $\mathrm{Mg}$ & 0.34 & -0.12 & $0.68 * *$ & 0.31 & -0.18 & 0.20 & -0.09 & -0.07 & 0.05 & \\
\hline SM 05 & 0.06 & 0.07 & -0.13 & $-0.62 * *$ & -0.33 & $-0.50 *$ & 0.02 & -0.01 & $-0.50 *$ & $---^{\mathrm{a}}$ \\
\hline SM 06 & -0.40 & 0.31 & -0.33 & $-0.62 * *$ & 0.02 & 0.17 & -0.46 & -0.06 & 0.17 & -0.23 \\
\hline SM 07 & $---^{a}$ & ---- & 0.16 & $-0.53^{*}$ & -0.32 & $-0.68 * *$ & 0.37 & 0.30 & $-0.62 * *$ & 0.04 \\
\hline Leaf $\psi 05$ & -0.42 & $0.51 *$ & -0.35 & -0.46 & 0.31 & -0.02 & -0.14 & 0.36 & 0.14 & -0.35 \\
\hline Leaf $\psi 06$ & -0.23 & 0.21 & 0.01 & 0.01 & $0.69 * *$ & 0.15 & 0.17 & $0.61 * *$ & 0.40 & -0.25 \\
\hline Leaf $\psi 07$ & -0.06 & 0.03 & -0.05 & -0.18 & $0.51 *$ & -0.02 & 0.16 & $0.77 * *$ & 0.29 & 0.02 \\
\hline \multicolumn{11}{|c|}{ George } \\
\hline Clay & $-0.88 * *$ & & & & & & & & & \\
\hline Soil $\mathrm{pH}$ & $-0.91 * *$ & $0.79 * *$ & & & & & & & & \\
\hline Soil OM & $-0.51 *$ & $0.50^{*}$ & 0.22 & & & & & & & \\
\hline CEC & -0.33 & 0.41 & 0.27 & $0.64^{* *}$ & & & & & & \\
\hline BS-Ca & $-0.89 * *$ & $0.82 * *$ & $0.89 * *$ & 0.35 & 0.10 & & & & & \\
\hline $\mathrm{P}$ & -0.35 & 0.35 & 0.64 & -0.44 & -0.15 & $0.53 *$ & & & & \\
\hline $\mathrm{K}$ & $-0.68 * *$ & $0.70 * *$ & $0.70 * *$ & 0.22 & 0.35 & $0.57^{*}$ & $0.60 * *$ & & & \\
\hline $\mathrm{Ca}$ & $-0.86^{* *}$ & $0.84 * *$ & $0.82 * *$ & $0.65 * *$ & $0.67 * *$ & $0.80 * *$ & 0.29 & $0.61 * *$ & & \\
\hline $\mathrm{Mg}$ & $-0.77 * *$ & $0.81 * *$ & $0.83 * *$ & 0.07 & 0.22 & $0.67 * *$ & $0.67 * *$ & $0.82 * *$ & $0.61 * *$ & \\
\hline SM 05 & -0.23 & 0.07 & 0.38 & -0.22 & -0.14 & 0.34 & $0.66^{* *}$ & 0.43 & 0.18 & 0.32 \\
\hline SM 06 & $-0.71 * *$ & $0.72 * *$ & $0.80 * *$ & 0.24 & $0.50 *$ & $0.72 * *$ & $0.68 * *$ & $0.78 * *$ & $0.78 * *$ & $0.75 * *$ \\
\hline SM 07 & -0.17 & 0.31 & 0.41 & $-0.51 *$ & -0.16 & 0.28 & $0.78 * *$ & 0.48 & 0.07 & $0.60 * *$ \\
\hline Leaf $\psi 05$ & -0.48 & $0.66^{* *}$ & 0.27 & $0.73^{* *}$ & 0.26 & $0.53 *$ & -0.05 & 0.46 & $0.54 *$ & 0.31 \\
\hline Leaf $\psi 06$ & -0.14 & 0.06 & 0.29 & $-0.62 * *$ & $-0.75 * *$ & 0.32 & 0.48 & -0.05 & -0.23 & 0.27 \\
\hline Leaf $\psi 07$ & 0.47 & -0.30 & $-0.54 *$ & -0.27 & $-0.75 * *$ & -0.30 & -0.30 & $-0.54 *$ & $-0.66 * *$ & -0.39 \\
\hline
\end{tabular}

Moreover, the hypothesis that the spatial variation would be stable temporally was also proven by the data. This hypothesis carried with it the assumption that soil water status zones as well as vine water status zones would be stable temporally. Stable water status zones might give opportunity for selective harvest of different sections of each block, if water status could be linked to fruit composition. Since this variation is often reflected in yield and fruit composition, it might be to the winemaker's advantage for these zones to be individually harvested, with the potential of separating high quality grapes from lesser quality ones (Bramley, 2001; 2002; 2005; Bramley et al., 2003). Therefore, it could be possible to produce premium quality wine from a portion of a vineyard block rather than blending all the fruit into a lower quality product.

Soil texture is an important factor that affects soil water retention. The available soil moisture ranges from $30 \mathrm{~mm} / \mathrm{m}$ of soil depth for sands to $160 \mathrm{~mm} / \mathrm{m}$ for clays (Goldberg et al., 1971). The capacity of soil to store water depends on root zone depth and soil water holding capacity. Infiltration rate also has significant effect on water supply (Smart and Coombe, 1983). Soil moisture values varied among vineyards as well as within vineyards in all three years. The lowest soil moisture values were observed at three sites (Hernder, Reif and Harbour) (Table 3). The low soil moisture values at these three sites were attributable to shallow soil profiles, higher content of gravel, and sandy loam soil textures, respectively, all of which do not allow for high water retention in the soil profile. The Hernder site had a clay loam-based soil texture but with a shallow soil profile with low water-holding capacity (Table 1). The Reif site also contained a clay loam soil texture but with considerable gravel that facilitated rapid soil drainage. The Harbour site, with 48\% sand, had a sandy loam soil texture that provided low soil moisture retention. Highest soil moisture values in 2005 were at the Buis site in a range of 14.0 to $20.4 \%$; in 2006 the highest soil moisture values were observed at the Vieni site with a range of 22.2 to $35.9 \%$, and in 2007 the Buis site again had the highest soil moisture with a range of 17.2 to $27.6 \%$. The Buis site had a deep loam soil with higher ability to hold water in the soil profile, while the Vieni site also had a clay loam till-based soil with high water-holding capacity. Overall, soil moisture values were higher in 2006 at all sites in comparison with 2005 and 2007 due to higher precipitation (Table 2).

It is worthy of note that Coipel et al. (2006) showed that soil texture and composition were not crucial to the terroir effect but soil depth was critical in terms of how it impacted vine water and nitrogen status. Shallow soils generally led to vines with low water status and low nitrogen, but also ultimately produced small berries that were high in Brix and anthocyanins. This was among the first studies to underscore the interactive effects of soil texture, vine water status, and nitrogen status. Our results likewise showed that the deeper, coarse-textured soils typically had high leaf $\psi$ values whereas the shallow, fine-textured clay and clay loam soils had low leaf $\psi$ values. 
Table 5 contd.

\begin{tabular}{|c|c|c|c|c|c|c|c|c|c|c|}
\hline & Sand & Clay & Soil $\mathrm{pH}$ & Soil OM & CEC & BS-Ca & $\mathrm{P}$ & $\mathrm{K}$ & $\mathrm{Ca}$ & $\mathrm{Mg}$ \\
\hline \multicolumn{11}{|c|}{ Cave Spring } \\
\hline Sand & & & & & & & & & & \\
\hline Clay & $-0.55^{*}$ & & & & & & & & & \\
\hline Soil pH & $-0.78 * *$ & 0.40 & & & & & & & & \\
\hline Soil OM & 0.27 & $-0.65 * *$ & -0.20 & & & & & & & \\
\hline CEC & $-0.80 * *$ & $0.62 * *$ & $0.93 * *$ & -0.46 & & & & & & \\
\hline $\mathrm{BS}-\mathrm{Ca}$ & $-0.79 * *$ & $0.60 * *$ & $0.91 * *$ & -0.46 & $0.94 * *$ & & & & & \\
\hline $\mathrm{P}$ & $-0.84 * *$ & 0.29 & $0.72 * *$ & -0.28 & $0.74 * *$ & $0.71 * *$ & & & & \\
\hline K & $-0.56^{*}$ & -0.08 & 0.37 & 0.04 & 0.32 & 0.40 & $0.82 * *$ & & & \\
\hline $\mathrm{Ca}$ & $-0.80 * *$ & $0.61 * *$ & $0.93 * *$ & -0.46 & $0.99 * *$ & $0.96 * *$ & $0.76^{* *}$ & 0.36 & & \\
\hline $\mathrm{Mg}$ & $0.83 * *$ & $-0.56^{*}$ & $-0.82 * *$ & 0.41 & $-0.83^{* *}$ & $-0.95 * *$ & $-0.77 * *$ & $-0.56^{*}$ & $-0.87 * *$ & \\
\hline SM 05 & $-0.73 * *$ & 0.15 & $0.56^{*}$ & -0.20 & $0.56^{*}$ & $0.54 *$ & $0.82 * *$ & $0.69 * *$ & $0.57 *$ & $-0.59 *$ \\
\hline SM 06 & $-0.61 * *$ & 0.14 & 0.38 & -0.20 & 0.45 & 0.31 & $0.75 * *$ & $0.56^{*}$ & 0.44 & -0.33 \\
\hline SM 07 & $-0.60 * *$ & 0.28 & $0.50^{*}$ & -0.25 & $0.57 *$ & 0.46 & $0.70 * *$ & 0.49 & $0.57 *$ & -0.47 \\
\hline Leaf $\psi 05$ & 0.09 & 0.11 & $-0.55^{*}$ & 0.02 & -0.46 & -0.37 & -0.28 & -0.13 & -0.46 & 0.22 \\
\hline Leaf $\psi 06$ & $0.57 *$ & 0.05 & $-0.56^{*}$ & -0.15 & $-0.50 *$ & -0.33 & $-0.52 *$ & -0.25 & -0.47 & 0.23 \\
\hline Leaf $\psi 07$ & $0.62 * *$ & -0.36 & -0.25 & 0.48 & -0.43 & -0.30 & $-0.71 * *$ & -0.49 & -0.42 & 0.32 \\
\hline \multicolumn{11}{|c|}{ Henry of Pelham } \\
\hline Clay & $-0.71 * *$ & & & & & & & & & \\
\hline Soil pH & $-0.65 * *$ & $0.85 * *$ & & & & & & & & \\
\hline Soil OM & $0.57 *$ & $-0.72 * *$ & -0.21 & & & & & & & \\
\hline CEC & $-0.60 * *$ & $0.92 * *$ & $0.93 * *$ & $-0.86 * *$ & & & & & & \\
\hline $\mathrm{BS}-\mathrm{Ca}$ & $-0.58^{*}$ & $0.82 * *$ & $0.97 * *$ & $-0.82 * *$ & $0.96 * *$ & & & & & \\
\hline $\mathrm{P}$ & $0.61 * *$ & -0.03 & -0.08 & 0.25 & -0.04 & -0.10 & & & & \\
\hline $\mathrm{K}$ & -0.39 & 0.14 & -0.09 & 0.04 & -0.09 & -0.23 & -0.05 & & & \\
\hline $\mathrm{Ca}$ & $-0.60 * *$ & $0.90 * *$ & $0.93 * *$ & $-0.87 * *$ & $0.99 * *$ & $0.97 * *$ & -0.06 & -0.12 & & \\
\hline $\mathrm{Mg}$ & -0.02 & 0.01 & -0.38 & 0.15 & -0.22 & -0.45 & 0.10 & $0.76^{* *}$ & -0.26 & \\
\hline SM 05 & -0.11 & $0.51 *$ & $0.50 *$ & -0.27 & $0.49 *$ & $0.51^{*}$ & 0.26 & -0.39 & $0.50 *$ & -0.42 \\
\hline SM 06 & 0.05 & 0.13 & 0.20 & -0.05 & 0.14 & 0.20 & 0.14 & -0.33 & 0.15 & -0.30 \\
\hline SM 07 & -0.03 & 0.24 & 0.32 & 0.08 & 0.16 & 0.23 & 0.37 & -0.16 & 0.17 & -0.32 \\
\hline Leaf $\psi 05$ & $-0.47 *$ & 0.36 & $0.60 * *$ & $-0.70 * *$ & $0.62^{* *}$ & $0.68^{* *}$ & -0.44 & -0.22 & $0.64 * *$ & $-0.47 *$ \\
\hline Leaf $\psi 06$ & $0.69 * *$ & $-0.50 *$ & -0.40 & 0.29 & -0.34 & -0.32 & 0.38 & -0.48 & -0.32 & -0.15 \\
\hline Leaf $\psi 07$ & $0.52 *$ & -0.29 & -0.28 & 0.31 & -0.31 & -0.32 & 0.48 & -0.27 & -0.29 & -0.12 \\
\hline
\end{tabular}

Leaf water potential: The role of vine water relations as an important driver of the terroir effect was established by both Seguin (1986) and van Leeuwen et al. (2004, 2009). It is likely that the effects of climate and soil on fruit composition are mediated through their influence on vine water status (Van Leeuwen et al., 2004). Generally, coarse-textured gravelly soils with exceptional drainage or shallow, fine-textured soils with low growth potential will lead to mild water stress in red wine cultivars, which consequently result in higher soluble solids and anthocyanins, and lower berry weights, vine size, and TA (van Leeuwen, 2010; van Leeuwen and Seguin, 1994; van Leeuwen et al., 2004; 2009). Work with Cabernet Franc in St. Emilion specifically underscored the importance of low leaf $\psi$ during the veraison to harvest period in terms of ultimate wine quality. Those sites with low vine water status had fruit with highest Brix, anthocyanins, and phenols (Van Leeuwen and Seguin, 1994).

The leaf $\psi$ values measured at the different sites are in the range commonly reported for irrigated grapevines in California (Williams and Matthews, 1990). High soil water availability at some sites likely reduced vine water stress by increasing leaf $\psi$ values. Leaf $\psi$ values varied within all vineyard blocks, enabling vine separation into high, medium and low water status categories for each vineyard block for all three years, and therefore the hypothesis that temporally-stable water status zones could be delineated was proven by the data in all three years. In 2005 and 2007, which were dry and hot years, the potential for water stress appeared earlier and was more severe. The highest and lowest mean leaf $\psi$ values, respectively, were observed at the Harbour (range -0.80 to $-1.09 \mathrm{MPa}$ ) and CDC sites (range -1.20 to $-1.60 \mathrm{MPa}$ ) in 2005 , at the Vieni (range -0.82 to $-1.10 \mathrm{MPa}$ ) and Hernder sites (range -1.29 to $-1.69 \mathrm{MPa}$ ) in 2006 , and at the Harbour (range -0.93 to $-1.12 \mathrm{MPa}$ ) and CDC sites (range -1.52 to $-1.64 \mathrm{MPa}$ ) in 2007 (Table 3). The potential for water stress was always more intense at the CDC (three year range 1.20 to $-1.64 \mathrm{MPa}$ ) and Hernder (three year range -1.26 to -1.60 $\mathrm{MPa})$ sites. The lowest leaf $\psi$ values at $\operatorname{CDC}(2005,2007)$ were possibly due to low precipitation in combination with the heavy lacustrine clay loam soil texture which, even with relatively high soil moisture in the soil profile (14 and $17.2 \%$ ), water was below wilting point $(<-1500 \mathrm{kPa}$ ) and therefore unavailable (Kingston and Presant, 1989). The low leaf $\psi$ values at the Hernder site were likely due to the shallow soil profile and the clay loam soil texture that had low available moisture in the profile (Kingston and Presant, 1989).

Grapevines growing in deep coarse sands or gravel may have roots penetrating to depths $>6 \mathrm{~m}$ (Smart and Coombe, 1983). High leaf $\psi$ values at the Harbour site could be due to the sandy loam soil texture as well as the deep soil profile that permitted vigorous vine growth and a deep rootsystem. The deep roots of these vines allowed water absorption from deeper soil layers; therefore vines at this site did not face water stress in any of the three years. Chardonnay vines that received irrigation at $100 \%$ of 
Table 5 contd.

\begin{tabular}{|c|c|c|c|c|c|c|c|c|c|c|}
\hline & Sand & Clay & Soil pH & Soil OM & $\mathrm{CEC}$ & BS-Ca & $\mathrm{P}$ & $\mathrm{K}$ & $\mathrm{Ca}$ & $\mathrm{Mg}$ \\
\hline \multicolumn{11}{|c|}{ Vieni } \\
\hline Clay & $-0.90 * *$ & & & & & & & & & \\
\hline Soil pH & $-0.61 * *$ & $0.79 * *$ & & & & & & & & \\
\hline Soil OM & $-0.51 *$ & 0.31 & -0.18 & & & & & & & \\
\hline $\mathrm{CEC}$ & $-0.60 * *$ & $0.69 * *$ & $0.96^{* *}$ & -0.21 & & & & & & \\
\hline BS-Ca & $-0.65 * *$ & $0.83 * *$ & $0.98 * *$ & -0.11 & $0.91 * *$ & & & & & \\
\hline $\mathrm{P}$ & -0.43 & 0.44 & 0.35 & $0.57 *$ & 0.30 & 0.37 & & & & \\
\hline $\mathrm{K}$ & -0.40 & 0.17 & 0.03 & $0.66^{* *}$ & 0.11 & 0.04 & $0.75 * *$ & & & \\
\hline $\mathrm{Ca}$ & $-0.63 * *$ & $0.78 * *$ & $0.99 * *$ & -0.18 & $0.98 * *$ & $0.98 * *$ & 0.33 & 0.06 & & \\
\hline $\mathrm{Mg}$ & $-0.83 * *$ & $0.78 * *$ & 0.51 & $0.71 * *$ & 0.46 & $0.57 *$ & $0.78 * *$ & $0.66^{* *}$ & $0.52 *$ & \\
\hline SM 05 & 0.16 & -0.02 & 0.36 & $-0.52 *$ & 0.42 & 0.28 & -0.04 & -0.13 & 0.36 & -0.21 \\
\hline SM 06 & 0.29 & -0.19 & 0.08 & -0.37 & 0.10 & -0.02 & -0.15 & -0.23 & 0.05 & -0.35 \\
\hline SM 07 & -0.25 & 0.36 & $0.52 *$ & 0.04 & $0.50^{*}$ & 0.46 & $0.57 *$ & 0.27 & $0.50 *$ & 0.36 \\
\hline Leaf $\psi 05$ & $0.64 * *$ & $-0.68 * *$ & $-0.74 * *$ & -0.30 & $-0.73 * *$ & $-0.72 * *$ & $-0.82 * *$ & $-0.65 * *$ & $-0.73 * *$ & $-0.78 * *$ \\
\hline Leaf $\psi 06$ & 0.16 & 0.12 & -0.08 & -0.22 & -0.28 & 0.001 & -0.35 & $-0.71 * *$ & -0.12 & -0.27 \\
\hline Leaf $\psi 07$ & $0.85 * *$ & $-0.79 * *$ & -0.43 & $-0.75 * *$ & -0.39 & -0.48 & $-0.63 * *$ & $-0.54 *$ & -0.44 & $-0.94 * *$ \\
\hline \multicolumn{11}{|c|}{ Morrison } \\
\hline Clay & $-0.84 * *$ & & & & & & & & & \\
\hline Soil pH & $-0.55^{*}$ & $0.58 *$ & & & & & & & & \\
\hline Soil OM & $0.52 *$ & $-0.72 * *$ & -0.47 & & & & & & & \\
\hline $\mathrm{CEC}$ & -0.42 & 0.36 & $0.81 * *$ & -0.42 & & & & & & \\
\hline BS-Ca & -0.05 & -0.13 & 0.48 & -0.21 & $0.83 * *$ & & & & & \\
\hline $\mathrm{P}$ & $0.50 *$ & 0.24 & 0.45 & 0.19 & 0.15 & -0.12 & & & & \\
\hline $\mathrm{K}$ & -0.13 & -0.08 & -0.26 & $0.59 *$ & $-0.51 *$ & $-0.63 * *$ & $0.67 * *$ & & & \\
\hline $\mathrm{Ca}$ & 0.28 & 0.15 & $0.67 * *$ & -0.34 & $0.96 * *$ & $0.94 * *$ & 0.02 & $-0.57 *$ & & \\
\hline $\mathrm{Mg}$ & -0.23 & $0.62 * *$ & 0.09 & -0.27 & -0.29 & $-0.73 * *$ & 0.07 & 0.18 & $-0.52 *$ & \\
\hline SM 05 & 0.33 & -0.20 & 0.01 & -0.05 & 0.35 & $0.52 *$ & $-0.62 * *$ & $-0.63 * *$ & 0.45 & -0.30 \\
\hline SM 06 & -0.11 & 0.15 & $0.56^{*}$ & $-0.50 *$ & $0.70 * *$ & $0.73 * *$ & -0.14 & $-0.63 * *$ & $0.73 * *$ & -0.35 \\
\hline SM 07 & -0.15 & 0.27 & $0.69 * *$ & -0.31 & $0.60 * *$ & 0.42 & 0.05 & -0.36 & $0.52 *$ & 0.06 \\
\hline Leaf $\psi 05$ & 0.33 & -0.32 & 0.07 & -0.22 & 0.47 & $0.78 * *$ & $-0.57 *$ & $-0.82 * *$ & $0.63 * *$ & $-0.62 * *$ \\
\hline Leaf $\psi 06$ & 0.03 & -0.19 & 0.33 & 0.13 & 0.40 & 0.40 & 0.23 & -0.08 & 0.40 & -0.31 \\
\hline Leaf $\psi 07$ & 0.41 & -0.22 & 0.33 & -0.17 & 0.35 & $0.50 *$ & -0.35 & $-0.68 * *$ & 0.39 & -0.18 \\
\hline
\end{tabular}

*, **: Significant at $p \leq 0.05$ or 0.01 (boldfaced values), respectively. ${ }^{a}$ Correlation coefficients were non-determinable.

evapotranspiration had leaf $\psi$ values of -1.0 MPa (Williams and Araujo, 2002), which suggests that vines at the Harbour site had adequate water availability, similar to that of irrigated vines. The high leaf $\psi$ values at Vieni in 2006 were due to high soil moisture in that year; in fact in 2006 the Vieni site had the highest soil moisture among all ten sites. Although leaf $\psi$ differed spatially within each of the vineyard blocks as well as across vineyards, the range of leaf $\psi$ values remained very consistent in most vineyard blocks in all years, even with the different weather conditions. The minimal temporal variation within the season suggests that the data density was sufficient.

Soil texture and composition: Spatial patterns were observed for all sites in terms of soil texture and composition variables, and several of these were related to soil and vine water status. Relationships among soil textural components (\% sand and clay), soil physical properties (CEC, BS, OM, pH), and major elements ( $\mathrm{P}, \mathrm{K}, \mathrm{Ca}, \mathrm{Mg}$ ) are widely known. For instance, as \% clay increases in a soil, generally soil moisture, as well as CEC, $\mathrm{BS}, \mathrm{K}, \mathrm{Ca}$, and $\mathrm{Mg}$ likewise will increase (Brady and Weil, 2002). In limestone-based soils in Ontario, this is often accompanied by increases in $\mathrm{pH}$ and $\mathrm{P}$ (Kingston and Presant, 1989). OM is also a contributing factor to soil moisture. Percent clay also may be inversely correlated spatially with yield and berry weight, and directly with anthocyanins and phenols (Bramley, 2001). Spatial relationships between yield and berry composition vs. soil and petiole elemental composition have likewise been demonstrated.
Zones of elevated soil and petiole $\mathrm{K}$ have been associated with zones of high TA, and patterns in $\mathrm{K}: \mathrm{Mg}$ ratios have been associated with spatial variability in yield and Brix (Bramley, 2001). Zones within vineyards with high \% clay may frequently be those zones with high soil moisture, as well as higher CEC, $\mathrm{BS}, \mathrm{K}, \mathrm{Mg}, \mathrm{Ca}$, and perhaps other elements, but the implications of these relationships for yield and wine quality will ultimately depend upon the potential for those high clay zones to drain sufficiently (Bramley, 2001).

\section{Temporal stability}

Soil moisture: The relevance of soil moisture data is strongly dependent upon the soil texture and the depth of the rootsystem. The majority of the rootsystems of grapevines are found in the top one meter of soil (van Zyl and Weber, 1981) (most of them in the upper 30 to $50 \mathrm{~cm}$ ), although a grapevine rootsystem may exceed $6 \mathrm{~m}$ in depth under some conditions (Smart and Coombe, 1983). The vineyard blocks in this study were all non-irrigated sites and would be expected to have roots growing deeply into the soil profile. However, the soil water table is relatively high in the Niagara region and drainage tiles are typically placed at $\mathrm{a} \approx 60 \mathrm{~cm}$ depth; hence most rootsystems, particularly those in lacustrine clays, are in the top 30 to $60 \mathrm{~cm}$. Soil moisture zones were temporally stable, particularly at the Reif site for 2005 and 2006 (Table 4). From 2006 to 2007, soil moisture zones were again temporally stable at all sites, most particularly Buis, Reif and CDC. Eight of ten locations were also temporally stable 
Table 6. Overall correlations and $\mathrm{p}$ values of soil factors for ten Cabernet Franc sites Niagara Peninsula, ON. 2005-07. Abbreviations: OM= organic matter; $\mathrm{CEC}=$ cation exchange capacity; $\mathrm{BS}=$ base saturation; $\mathrm{SM}=$ soil moisture

\begin{tabular}{|c|c|c|c|c|c|c|c|c|c|c|c|c|c|c|c|c|}
\hline & $\begin{array}{l}\text { Sand } \\
(\%)\end{array}$ & $\begin{array}{l}\text { Clay } \\
(\%)\end{array}$ & $\begin{array}{l}\text { OM } \\
(\%)\end{array}$ & $\begin{array}{c}\text { CEC } \\
\text { (meq/ } \\
100 \mathrm{~g})\end{array}$ & $\begin{array}{l}\text { Soil } \\
\mathrm{pH}\end{array}$ & $\begin{array}{c}\mathrm{BS} \\
(\% \mathrm{Ca})\end{array}$ & $\begin{array}{c}\mathrm{P} \\
(\mathrm{ppm})\end{array}$ & $\begin{array}{c}\mathrm{K} \\
(\mathrm{ppm})\end{array}$ & $\begin{array}{c}\mathrm{Ca} \\
(\mathrm{ppm})\end{array}$ & $\begin{array}{c}\mathrm{Mg} \\
(\mathrm{ppm})\end{array}$ & $\begin{array}{c}\text { SM } \\
(\%) \\
2005\end{array}$ & $\begin{array}{c}\psi \\
(-\mathrm{MPa}) \\
2005\end{array}$ & $\begin{array}{c}\text { SM } \\
(\%) \\
2006\end{array}$ & $\begin{array}{c}\psi \\
(-\mathrm{MPa}) \\
2006\end{array}$ & $\begin{array}{c}\text { SM } \\
(\%) \\
2007\end{array}$ & $\begin{array}{c}\psi \\
(-\mathrm{MPa}) \\
2007\end{array}$ \\
\hline \multirow[t]{2}{*}{$\%$ Sand } & 1.000 & -0.895 & -0.218 & -0.641 & -0.526 & -0.615 & 0.205 & 0.175 & -0.613 & -0.623 & -0.135 & -0.597 & -0.654 & -0.179 & -0.262 & -0.541 \\
\hline & & $<.0001$ & 0.0055 & $<.0001$ & $<.0001$ & $<.0001$ & 0.0092 & 0.0266 & $<.0001$ & $<.0001$ & 0.0871 & $<.0001$ & $<.0001$ & 0.0223 & 0.0004 & $<.0001$ \\
\hline \multirow[t]{2}{*}{$\%$ Clay } & & 1.000 & 0.156 & 0.629 & 0.511 & 0.610 & -0.280 & -0.101 & 0.589 & 0.647 & 0.013 & 0.726 & 0.693 & 0.386 & 0.376 & 0.662 \\
\hline & & & 0.0489 & $<.0001$ & $<.0001$ & $<.0001$ & 0.0003 & 0.2013 & $<.0001$ & $<.0001$ & 0.8709 & $<.0001$ & $<.0001$ & $<.0001$ & $<.0001$ & $<.0001$ \\
\hline \multirow[t]{2}{*}{$\% \mathrm{OM}$} & & & 1.000 & 0.087 & 0.037 & 0.049 & 0.092 & 0.135 & 0.039 & 0.403 & -0.013 & 0.216 & 0.174 & 0.110 & 0.153 & 0.221 \\
\hline & & & & 0.2728 & 0.6447 & 0.5385 & 0.2476 & 0.0889 & 0.6258 & $<.0001$ & 0.8689 & 0.0060 & 0.0265 & 0.1639 & 0.0403 & 0.0029 \\
\hline \multirow{2}{*}{$\begin{array}{l}\text { CEC } \\
(\mathrm{meq} / 100 \mathrm{~g})\end{array}$} & & & & 1.000 & 0.768 & 0.755 & -0.030 & -0.146 & 0.989 & 0.347 & 0.268 & 0.429 & 0.436 & 0.237 & 0.366 & 0.366 \\
\hline & & & & & $<.0001$ & $<.0001$ & 0.7082 & 0.0648 & $<.0001$ & $<.0001$ & 0.0006 & $<.0001$ & $<.0001$ & 0.0024 & $<.0001$ & $<.0001$ \\
\hline \multirow[t]{2}{*}{ Soil $\mathrm{pH}$} & & & & & 1.000 & 0.891 & -0.092 & -0.149 & 0.815 & 0.341 & 0.139 & 0.358 & 0.315 & 0.185 & 0.339 & 0.281 \\
\hline & & & & & & $<.0001$ & 0.2465 & 0.0595 & $<.0001$ & $<.0001$ & 0.0786 & $<.0001$ & $<.0001$ & 0.0184 & $<.0001$ & 0.0001 \\
\hline \multirow{2}{*}{$\begin{array}{l}\mathrm{BS} \\
(\% \mathrm{Ca})\end{array}$} & & & & & & 1.000 & -0.169 & -0.160 & 0.813 & 0.347 & 0.190 & 0.505 & 0.404 & 0.302 & 0.471 & 0.370 \\
\hline & & & & & & & 0.0326 & 0.0421 & $<.0001$ & $<.0001$ & 0.0158 & $<.0001$ & $<.0001$ & $<.0001$ & $<.0001$ & $<.0001$ \\
\hline \multirow[t]{2}{*}{$\mathrm{P}(\mathrm{ppm})$} & & & & & & & 1.000 & 0.609 & -0.021 & -0.450 & 0.029 & -0.130 & 0.037 & -0.050 & -0.039 & 0.146 \\
\hline & & & & & & & & $<.0001$ & 0.7872 & $<.0001$ & 0.7114 & 0.0991 & 0.6406 & 0.5276 & 0.6077 & 0.0505 \\
\hline \multirow[t]{2}{*}{$\mathrm{K}(\mathrm{ppm})$} & & & & & & & & 1.000 & -0.154 & -0.255 & -0.183 & 0.049 & -0.074 & 0.219 & 0.028 & 0.231 \\
\hline & & & & & & & & & 0.0511 & 0.0011 & 0.0199 & 0.5375 & 0.3481 & 0.0070 & 0.7088 & 0.0019 \\
\hline \multirow[t]{2}{*}{$\mathrm{Ca}(\mathrm{ppm})$} & & & & & & & & & 1.000 & 0.292 & 0.269 & 0.392 & 0.386 & 0.218 & 0.358 & 0.322 \\
\hline & & & & & & & & & & 0.0002 & 0.0006 & $<.0001$ & $<.0001$ & 0.0051 & $<.0001$ & $<.0001$ \\
\hline \multirow[t]{2}{*}{$\mathrm{Mg}(\mathrm{ppm})$} & & & & & & & & & & 1.000 & 0.038 & 0.436 & 0.612 & 0.015 & 0.204 & 0.326 \\
\hline & & & & & & & & & & & 0.6289 & $<.0001$ & $<.0001$ & 0.8451 & 0.0062 & $<.0001$ \\
\hline \multirow[t]{2}{*}{ SM (\%) 2005} & & & & & & & & & & & 1.000 & -0.095 & 1.000 & 0.218 & 1.000 & 0.418 \\
\hline & & & & & & & & & & & & 0.2266 & & 0.0052 & & $<.0001$ \\
\hline$\psi(-\mathrm{MPa}) 2005$ & & & & & & & & & & & & 1.000 & - & 1.000 & - & 1.000 \\
\hline
\end{tabular}

when comparing 2005 and 2007. Therefore, the hypothesis that soil moisture zones would be consistent and stable temporally within vineyard blocks was supported by the data from 2005 to 2006, and was also sufficiently proven by the 2006 to 2007 data. The reason for any lack in temporal stability could be in part due to the overall volatility of weather conditions in the region, and the particularly low precipitation in 2005 and 2007. The moisture variation in the upper $30 \mathrm{~cm}$ of soil can be high, and small volumes of precipitation can consequently result in high soil moisture readings. Therefore, in years of high rainfall, heavy clay soils with low infiltration rates will have high soil moisture in the upper portions of the soil profile, whereas the lower layers might be drier. On the other hand, during seasons with low precipitation, the upper portions of the soil profile may be dry and low soil moisture values are typically obtained, even though lower layers of soil may contain moisture.

Leaf water potential: Perhaps the first published use of geomatic tools to map vine water status showed some clear spatial correlations between berry carbon isotope concentration $\left(\sigma^{13} \mathrm{C}\right)$ and stem $\psi$ (Van Leeuwen et al., 2006). This supported data showing relationships between predawn leaf $\psi$ and berry ${ }^{13} \mathrm{C}$ (Gaudillère et al., 2002). In the present study, leaf $\psi$ zones were only occasionally temporally stable, e.g. at the Harbour and Hernder sites from 2005 to 2006, and at the Harbour and Reif sites from 2006 to 2007 (Table 3). At the Harbour site, leaf $\psi$ zones were stable over all three years, possibly as a consequence of the likelihood of deep root systems afforded by the sandy soil at that site. Therefore, the hypothesis that water-status zones would be consistent within vineyard blocks was at best partially supported by the data. Considering that soil texture was stable at each site, and water holding capacity of each soil was also consistent, the only difference was the amount of precipitation in each year. It is safe to assume that since the average volume of water in the soil profile changes between years so does vine water status likewise change. There may, however, be relevant variables associated with soil texture and soil water holding capacity that may vary spatially and temporally. In a study on spatial variability in a Riesling vineyard in Ontario, specific areas of the vineyard that produced high yields or high concentrations of monoterpenes were transient and that their spatial distribution varied temporally (Reynolds et al., 2007; 2010a). Willwerth et al. (2010) demonstrated temporally-stable spatial inverse correlations between Riesling monoterpenes and leaf $\psi$. Nonetheless, our data suggest that caution must be exercised in using leaf $\psi$ measurements as the basis for precision viticulture, since spatial distribution of leaf $\psi$ may vary temporally, which makes selected harvest based on leaf $\psi$ values challenging. It is very likely that a greater density of sampling may have led to more widespread temporal stability in leaf $\psi$ patterns throughout the vineyards.

In situations where leaf $\psi$ does not vary temporally, this knowledge might allow implementation of specific viticultural practices in high water status situations (canopy management, crop reduction) or in drought situations (e.g. deficit irrigation) (Van Leeuwen et al., 2009). There is also potential for establishing temporally-stable zones of different flavor potential (Willwerth et al., 2010). In Cabernet Franc, 2-methoxy-3-isobutylpyrazine (IBMP) is ubiquitous worldwide, and a substantial soil-based influence has been demonstrated (less IBMP in gravel soils) 
(Peyrot des Gachons et al., 2005; Roujou de Boubée et al., 2000). The norisoprenoid $\beta$-damascenone has a substantial impact on wine aroma; by itself (apple notes), by enhancement of odor activity (increased fruity notes) of ethyl cinnamates and ethyl caproate, and by suppression of odor activity of IBMP in cultivars such as Cabernet Franc; its concentration varies according to soil type (Pineau et al., 2007). Cysteine precursors of odor-active thiol compounds were closely linked to N status in Sauvignon blanc, and high $\mathrm{N}$ zones within vineyards can potentially increase its varietal typicity (Choné et al., 2006).

Precision viticulture: For the results of this study to be useful, the patterns of variation within vineyard blocks must be constant from year to year. Although the absolute values of yield and berry composition for a vineyard may vary from vintage to vintage, the patterns of variation within blocks are normally stable (Bramley, 2005). In this study, variation in soil composition, soil moisture, leaf $\psi$, yield components and fruit composition was demonstrated in all vineyard blocks either by statistical analysis or by interpolation of GIS maps. The patterns of variation, however, were not temporally consistent from year to year for all variables at all sites. Precision viticulture is dependent on the existence of stable variability in patterns that can be managed effectively. If such variability does not exist, then a uniform management system is less expensive and more effective. To mitigate against possible variability, vines could be planted and trained within zones of similar soil texture, therefore reducing the need to manage them differentially afterwards. By differential planting, one can impose uniform management, which is more economical than uniformly planting and differentially managing (Bramley, 2005). Although studies comparing uniform planting/differential management vs. differential planting/uniform management appear not to exist in the literature, our data suggests that longer periods of study would help to elucidate these trends.

There are implications from these geomatic studies for precision viticulture, if spatial variability in vine vigor and yield can be found to be highly correlated, and if spatial variation in yield or other variables are temporally consistent within individual vineyard blocks. Precision viticulture is an appropriate means to make use of this vineyard variability for commercial purposes. Precision viticulture can be used for many purposes, from increasing precision of vine nutrition to the designation of subblocks for separate wine products. In terms of managing crop nutrition, petioles may be sampled using geo-referenced sampling points by GPS, whereby a vineyard manager is enabled to supply proper nutrients necessary for individual vines rather than uniform fertilization of entire vineyard (Bramley et al., 2003). As to designating sub-blocks, yield may vary with the percentage and position of clay in the soil profile (Bramley, 2001). In a specific example, spatial variation in yield in a vineyard in Coonawarra, Australia, was shown to be temporally stable over a 3-year period, whereby the low yielding areas corresponded with areas where the clay subsoil occurred close to the surface; and these areas were more prone to waterlogging in wet years. Different sensory characteristics were produced in wines made from these different zones (Bramley, 2001; 2002).

Under the conditions of this study, midday leaf $\psi$ measured several times throughout the season was a reliable indicator of vine water status and correlated closely with soil moisture. Soil moisture zones were temporally consistent at nine of ten sites from 2005 to 2006 and at all ten sites from 2006 to 2007. Vine water status zones (based on leaf $\psi$ ) were temporally consistent at two sites from 2005 to 2006 and at two sites from 2006 to 2007. Specific areas of vineyards with high and low water status appeared to be transient at most sites and their spatial distribution varied temporally (except Harbour Estate that showed consistent water status zones from 2005 to 2007). Soil moisture and leaf $\psi$ were inversely correlated with $\%$ sand and directly correlated with \% clay, CEC, soil pH, BS, and $\mathrm{K}, \mathrm{Ca}$, and $\mathrm{Mg}$. Spatial correlation analyses between soil moisture and leaf $\psi$, and several soil texture and composition variables, including $\mathrm{OM}, \mathrm{CEC}, \mathrm{pH}$ and $\mathrm{BS}, \mathrm{K}, \mathrm{P}, \mathrm{Ca}$ and $\mathrm{Mg}$ were consistent but also demonstrated a few site-specific relationships. These data suggest that low soil moisture and low vine water status zones in vineyards are related to corresponding areas of low \% clay, $\mathrm{OM}, \mathrm{CEC}$, soil $\mathrm{pH}, \mathrm{BS}$, and soil $\mathrm{K}, \mathrm{Ca}$, and $\mathrm{Mg}$. These data further suggest that precision viticulture techniques may be utilized in this region to soil texture, soil moisture, or vine water status-based vineyard sub-zones that could further relate to differing quality levels.

\section{Acknowledgements}

Authors wish to thank the Natural Sciences and Engineering Research Council of Canada and the Wine Council of Ontario for funding. The participation of all grape growers is also acknowledged.

\section{References}

Brady, N.C. and R.R. Weil, 2002. The nature and properties of soils. Thirteenth Edition. Prentice Hall, Upper Saddle River, NJ.

Bramley, R.G.V. 2001. Progress in the development of precision viticulture-variation in yield, quality and soil properties in contrasting Australian vineyards. In: Precision Tools for Improving Land Management. L.D. Currie and P. Loganathan P. (Eds.). Occasional Report No 14. Massey University, New Zealand.

Bramley, R.G.V. 2002. Towards optimal resource management for grape and wine production. In: Proceedings of the $11^{\text {th }}$ Australian wine industry technical conference. R.J. Blair, P.J. Williams and P.B. Høj (Eds.), Winetitles, Adelaide. pp. 274-275.

Bramley, R.G.V. 2005. Understanding variability in winegrape production systems. 2. Within vineyard variation in quality over several vintages. Austral. J. Grape and Wine Res., 11: 33-42.

Bramley, R.G.V., B. Pearse and P. Chamberlin, 2003. Being profitable precisely - a case study of precision viticulture from Margaret River. Austral. New Zealand Grapegrower and Winemaker. Annual Technical Issue, pp. 84-87.

CSSS (Canadian Society of Soil Science). 1993. Soil Sampling And Methods of Analysis. MR Carter (Ed.). Lewis Publishers, Boca Raton, FL.

Choné, X., V. Lavigne-Cruege, T. Tominaga, C. van Leeuwen, C. Castagnede, C. Saucier and D. Dubourdieu, 2006. Effect of vine nitrogen status on grape aromatic potential: flavor precursors (Scysteine conjugates), glutathione and phenolic content in Vitis vinifera L. cv. Sauvignon blanc grape juice. J. International des Sciences de la Vigne et du Vin, 40: 1-6.

Coipel J., B. Rodriguez-Lovelle, C. Sipp and C. van Leeuwen, 2006. Terroir effect, as a result of environmental stress, depends more on soil depth than on soil type (Vitis vinifera L. cv. Grenache noir, Côtes du Rhône, France, 2000). J. Int. Sci. de la Vigne et du Vin, 40: $177-185$.

Cortell, J.M., M. Halbleib, A.V. Gallagher, T.L. Righetti and J.A. Kennedy, 2006. Influence of vine vigor on grape (Vitis vinifera L. cv. Pinot Noir) anthocyanins. 1. Anthocyanin concentration and composition in fruit. J. Agric. Food Chem., 55: 6575-6584. 
Davenport, J.R., L.J. Mills, J.M. Tarara, F.J. Pierce and S. Lang, 2001. Application of GPS, GIS, yield monitors and ${ }^{\circ}$ Brix monitors for effective vineyard management. In: Proceedings of space age winegrowing symposium. A.G. Reynolds (Ed.), ASEV/ES Annual Meeting, Niagara-on-the-Lake, ON, July 11-12, 2001. ASEV/ES, Geneva, NY. pp. 50-55.

Gaudillère, J.P., C. van Leeuwen and N. Ollat, 2002. Carbon isotope composition of sugars in grapevine, an integrated indicator of vineyard water status. J. Exp. Bot., 53: 757-763.

Goldberg, S.D., M. Rinot and N. Karu, 1971. Effects of trickle irrigation intervals on distribution and utilization of soil moisture in a vineyard. Soil Sci. Soc. Amer. Proc., 35: 127-130.

Greenspan, M.D. and J.J O'Donnell, 2001. Evaluating the utility of remotely sensed canopy density for the understanding of vineyard spatial variability. In: Proceedings of space age winegrowing symposium. A.G. Reynolds (Ed.), ASEV/ES Annual Meeting, Niagara-on-the-Lake, ON, July 11-12, 2001. ASEV/ES, Geneva, NY. pp. 27-41.

Hakimi Rezaei, J. 2009. Delineation of within-site terroir effects using soil and vine water measurement. Investigation of Cabernet Franc. $\mathrm{PhD}$ Thesis, Brock University, St. Catharines, Ontario, Canada.

Hakimi Rezaei, J. and A.G. Reynolds, 2010a. Characterization of Niagara Peninsula Cabernet Franc wines by sensory analysis. Amer. J. Enol. Vitic., 61: 1-14.

Hakimi Rezaei, J. and A.G. Reynolds, 2010b. Impact of vine water status on sensory evaluation of Cabernet Franc wines in the Niagara Peninsula of Ontario. J. Int. Sci. de la Vigne et du Vin, 44: 61-75.

Hall A., D.W. Lamb, B. Holzapfel and J. Louis, 2002. Optical remote sensing applications in viticulture-a review. Austral. J. Grape Wine Res., 8: 36-47.

Johnson, L., B. Lobitz, R. Armstrong, R. Baldy, E. Weber, J. de Benedictis and D. Bosch, 1996. Airborne imaging aids vineyard canopy evaluation. California Agric., 50: 14-18.

Kingston, M.S. and E.W. Presant, 1989. The soils of the Regional Municipality of Niagara. Volume 2. Rept. No. 60 of the Ont. Institute of Pedology, $131 \mathrm{pp}$.

Peyrot des Gachons, C., C. van Leeuwen, T. Tominaga, J.-P. Soyer, J.P. Gaudillère and D. Dubourdieu, 2005. The influence of water and nitrogen deficit on fruit ripening and aroma potential of Vitis vinifera L. cv Sauvignon blanc in field conditions. J. Sci. Food Agric., 85: 73-85.

Pineau, B., J.C. Barbe, C. van Leeuwen and D. Dubourdieu, 2007. Which impact for $\beta$-damascenone on red wine aroma? J. Agric. Food Chem., 55: 4103-4108.

Proffitt, T., R.G.V. Bramley, D. Lamb and E. Winter, 2006. Precision viticulture. A new era in vineyard management and wine production. Winetitles, Ashford, South Australia.

Reynolds, A.G. and C. de Savigny, 2001. Use of GPS and GIS to determine the basis for terroir. In: Proceedings of space age winegrowing symposium. A.G. Reynolds (Ed.), ASEV/ES Annual Meeting, Niagara-on-the-Lake, ON, July 11-12, 2001. ASEV/ES, Geneva, NY. pp. 79-102.

Reynolds, A.G., C. de Savigny and J.J. Willwerth, 2010a. Riesling terroir in Ontario vineyards. The roles of soil texture, vine size and vine water status. Progres Agric. et Vitic., 127(10): 212-222.

Reynolds, A.G., M. Marciniak, R.B. Brown, L. Tremblay and L. Baissas, 2010b. Using GPS, GIS and airborne imaging to understand Niagara terroir. Progres Agric. et Vitic., 127(12): 259-274.
Reynolds, A.G., I.V. Senchuk, C. van der Reest and C. de Savigny, 2007. Use of GPS and GIS for elucidation of the basis for terroir: Spatial variation in an Ontario Riesling vineyard. Amer. J. Enol. Vitic., 58: 145-162.

Roujou de Boubée, D., C. van Leeuwen and D. Dubourdieu, 2000. Organoleptic impact of 2-methoxy-3-isobutylpyrazine on red Bordeaux and Loire wines. Effect of soil and climate parameters on concentration in grapes during ripening. J. Agric. Food Chem., 48: 4830-4834.

Seguin, G. 1986. Terroirs and pedology of wine growing. Experientia, 42: 861-873.

Smart, R.E. and B.G. Coombe, 1983. Water relations of grapevines. In: Water Deficits and Plant Growth. T.T. Kozlowski (Ed.). Academic Press, New York. pp.137-196

Steel, R.G.D. and J.H. Torrie, 1960. Principles and Procedures of Statistics. McGraw Hill, New York, Toronto, London.

Turner, N.C. 1988. Measurement of plant water status by the pressure chamber technique. Irrigation Sci., 9: 289-308.

van Leeuwen, C. 2010. Terroir: the effect of the physical environment on vine growth, grape ripening and wine sensory attributes. In: Managing Wine Quality, Volume 1: Viticulture and Wine Quality, A.G. Reynolds, Ed., Woodhead Publishing Ltd., Oxford, UK. pp. 273-315.

van Leeuwen C., P. Friant, X. Choné, O. Tregoat, S. Koundouras and D. Dubourdieu, 2004. The influence of climate, soil and cultivar on terroir. Amer. J. Enol. Vitic., 55: 207-217.

van Leeuwen, C., J.P. Goutouly, C. Azais, A.M. Costa-Ferreira, E. Marguerit, J.P. Roby, X. Choné and J.P. Gaudillère, 2006. Intra-block variations of vine water status in time and space. $\mathrm{VI}^{\text {th }}$ international terroir congress, 2-7 July 2006, ENITA de Bordeaux - Syndicat Vitic. des Coteaux du Languedoc, France, pp. 64-69.

van Leeuwen, C. and G. Seguin, 1994. Incidences de l'alimentation en eau de la vigne, appréciée par l'état hydrique du feuillage, sur le développement de l'appareil végétatif et la maturation du raisin (Vitis vinifera variété Cabernet Franc, Saint-Emilion, 1990). J. Int. Sci. de la Vigne et du Vin, 28: 81-110.

van Leeuwen, C., O. Trégoat, X. Choné, B. Bois, D. Pernet and J.P. Gaudillère, 2009. Vine water status is a key factor in grape ripening and vintage quality for red Bordeaux wine. How can it be assessed for vineyard management purposes? J. Int. Sci. de la Vigne et du Vin, 43: 121-134.

Van Zyl J.L. and H.W. Weber, 1981. The effect of various supplementary irrigation treatments on plant and soil moisture relationships in a vineyard (Vitis vinifera var. Chenin blanc). South African J. Enol. Vitic., 2: 83-99.

Williams, L.E. and F.J. Araujo, 2002. Correlations among predawn leaf, midday leaf and midday stem water potential and their correlations with other measures of soil and plant water status in Vitis vinifera. Amer. J. Enol. Vitic., 53: 448-545.

Williams, L.E. and M.A. Matthews, 1990. Grapevine. In: Irrigation of agricultural crops. B.A. Stewart and D.R. Nielson (Eds.), American Society of Agronomy, Madison, WI. pp. 1019-1055.

Willwerth, J.J., A.G. Reynolds and I. Lesschaeve, 2010. Terroir factors: Their impact in the vineyard and on the sensory profiles of Riesling wines. Progres Agric. et Vitic., 127(8): 159-168.

Received: October, 2013; Revised: March, 2014; Accepted: March, 2014 